Article

\title{
Design, Synthesis and Evaluation of Novel Phthalimide Derivatives as in Vitro Anti-Microbial, Anti-Oxidant and Anti-Inflammatory Agents
}

\author{
Phoebe F. Lamie ${ }^{1, *}$, John N. Philoppes ${ }^{1}$, Ahmed O. El-Gendy ${ }^{2}$, Lucie Rarova ${ }^{3}$ and Jiri Gruz ${ }^{3}$ \\ 1 Department of Pharmaceutical Organic Chemistry, Faculty of Pharmacy, Beni Suef University, \\ Beni Suef 62514, Egypt; E-Mail: john_philoppes@yahoo.com \\ 2 Department of Microbiology \& Immunology, Faculty of Pharmacy, Beni Suef University, \\ Beni Suef 62514, Egypt; E-Mail: dr.ahmed_micro@yahoo.com \\ 3 Laboratory of Growth Regulators \& Department of Chemical Biology and Genetics, \\ Centre of the Region Haná for Biotechnological and Agricultural Research, \\ Institute of Experimental Botany ASCR \& Palacký University, Šlechtitelů 27, 78371 Olomouc, \\ The Czech Republic; E-Mails: lucie.rarova@upol.cz (L.R.); jiri.gruz@upol.cz (J.G.) \\ * Author to whom correspondence should be addressed; E-Mail: feby.farag@yahoo.com or \\ feebi.lamey@pharm.bsu.edu.eg; Tel.: +20-82-266-76; Fax:+20-82-231-7958.
}

Academic Editor: Roman Dembinski

Received: 26 June 2015 / Accepted: 20 August 2015 / Published: 14 September 2015

\begin{abstract}
Sixteen new phthalimide derivatives were synthesized and evaluated for their in vitro anti-microbial, anti-oxidant and anti-inflammatory activities. The cytotoxicity for all synthesized compounds was also determined in cancer cell lines and in normal human cells. None of the target derivatives had any cytotoxic activity. (ZE)-2-[4-(1-Hydrazono-ethyl) phenyl]isoindoline-1,3-dione (12) showed remarkable anti-microbial activity. Its activity against Bacillus subtilis was 133\%, 106\% and 88.8\% when compared with the standard antibiotics ampicillin, cefotaxime and gentamicin, respectively. Compound $\mathbf{1 2}$ also showed its highest activities in Gram negative bacteria against Pseudomonas aeruginosa where the percentage activities were $75 \%$ and $57.6 \%$ when compared sequentially with the standard antibiotics cefotaxime and gentamicin. It was also found that the compounds 2-[4-(4-ethyl-3methyl-5-thioxo-1,2,4-triazolidin-3-yl)phenyl]isoindoline-1,3-dione (13b) and 2-[4-(3-methyl5-thioxo-4-phenyl-1,2,4-triazolidin-3-yl)phenyl]isoindoline-1,3-dione (13c) had anti-oxidant activity. 4-( $N^{\prime}$-\{1-[4-(1,3-Dioxo-1,3-dihydro-isoindol-2-yl)-phenyl]-ethylidene $\}$-hydrazino)benzenesulfonamide (17c) showed the highest in vitro anti-inflammatory activity of the
\end{abstract}


tested compounds (a decrease of 32\%). To determine the mechanism of the anti-inflammatory activity of 17c, a docking study was carried out on the COX-2 enzyme. The results confirmed that $17 \mathrm{c}$ had a higher binding energy score $(-17.89 \mathrm{kcal} / \mathrm{mol})$ than that of the ligand celecoxib $(-17.27 \mathrm{kcal} / \mathrm{mol})$.

Keywords: synthesis; phthalimides; anti-microbial; anti-oxidant; anti-inflammatory

\section{Introduction}

The most important biological activity properties that have been reported for phthalimide (isoindoline-1,3-dione) derivatives $\mathbf{1}$ are anti-cancer [1], anti-microbial [2,3], anti-oxidant [4] and anti-inflammatory [5]. According to the World Health Organization (WHO), infectious and parasitic diseases are still the second cause of death worldwide. This is assumed to be due to resistance to the anti-microbial agents used. There are a number of studies showing that compounds bearing a phthalimide core may be a scaffold for designing new anti-microbial agents [2]. On the other hand, oxidation results in free radicals which damage the cell via causing oxidative stress leading to inflammation [6].

A literature search of suitable nuclei of use as anti-oxidant and anti-inflammatory agents, revealed phthalimide was one of these heterocyclic compounds $[1,4,5]$. The chemical core of phthalimides (-CO-N(R)-CO-) shows they are hydrophobic and this increases their potential to cross biological membranes in vivo [7]. To increase the biological activity of phthalimide derivatives, a molecular hybridization approach was used to introduce different pharmacophore subunits such as pyrazoles, diazoles, (oxo and thioxo) triazoles, benzo- (oxazoles, imidazoles and thiazoles) and compounds with the azomethine group (Schiff basses). Earlier described synthons have been reported to have anti-microbial [8], anti-oxidant [9] and anti-inflammatory [10-13] activities, apart from other pharmacological actions like anti-convulsant [14], CNS depressant [15], anti-tumor [1,16], anti-proliferative [17] and anti-pyretic [18] effects.

Inspection of the compounds $\mathbf{2}-\mathbf{8}$ depicted in Figure 1 led us to design and synthesize some new compounds containing mainly a phthalimide core and enhanced by certain pharmacophores. The aim was to find new agents with anti-microbial, anti-oxidant and anti-inflammatory effects. All the obtained new derivatives were tested as anti-microbial agents $\left(\mathrm{G}^{+}, \mathrm{G}^{-}\right.$bacteria and fungi) and studied for their anti-oxidant and anti-inflammatory activities using in vitro methods, (Figure 1).<smiles>[R]N1C(=O)c2ccccc2C1=O</smiles>

(1)

$N$-Substituted phthalimide

Figure 1. Cont. 


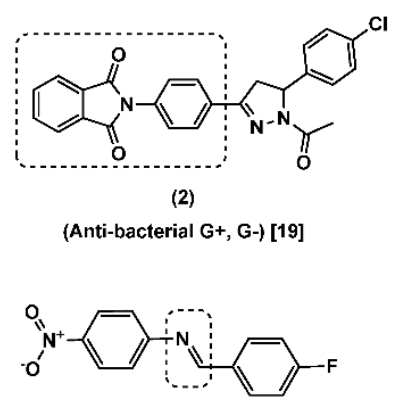

(4)

(Antioxidant) [20]

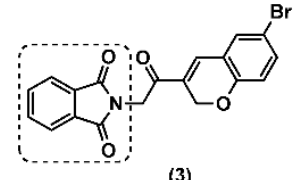

(3)
RAR2

(Antibacterial, antioxidant) [4]

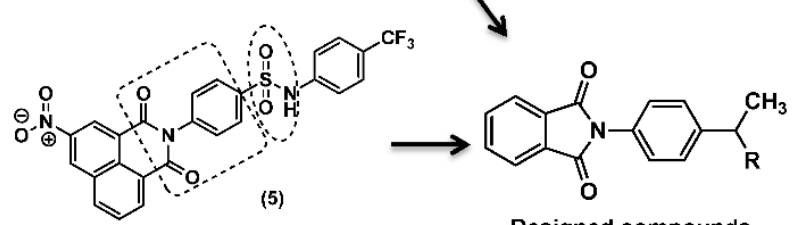

Designed compounds

(10a-c:17a-c)

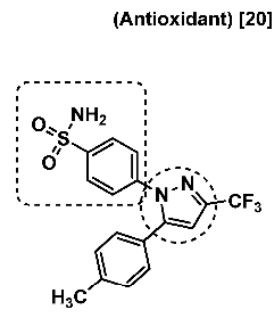

(6)

Celecoxib

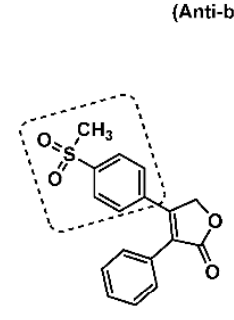

(7)

Rofecoxi

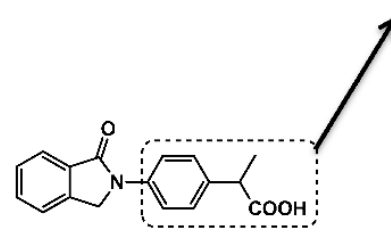

(8)

Indoprofen

(Selective CoX-2 inhibitors) [21] (Non-selective anti-inflammatory agent) [10]

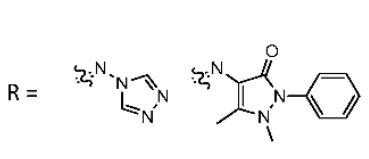

10a

$10 \mathrm{~b}$
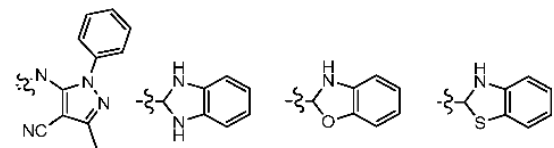

$10 \mathrm{c}$

11a

11b

$11 \mathrm{c}$
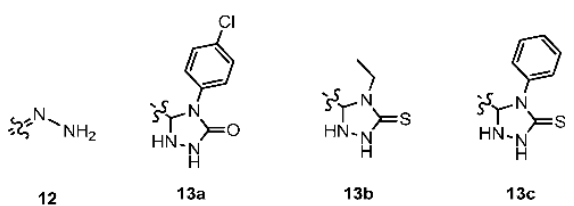

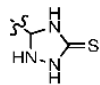

$13 \mathrm{~b}$

$13 c$

14

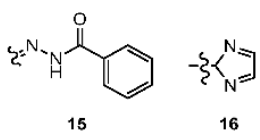

$S_{N^{2}}+\underbrace{}_{17 a}$

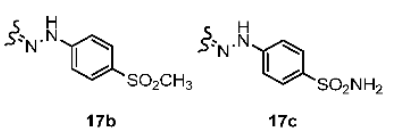

Figure 1. Representative examples of anti-microbial, anti-oxidant and anti-inflammatory agents and structural rationalization of the newly designed compounds.

\section{Results and Discussion}

\subsection{Chemical Synthesis}

The synthetic procedures adopted to obtain the target compounds are depicted in Schemes 1-3. Reaction of 2-(4-acetyl-phenyl)-isoindoline-1,3-dione (9), which was prepared according to the reported method [19], with equimolar amounts of primary amine derivatives, namely 1-aminotriazole, 4-amino1,5-dimethyl-2-phenyl-1,2-dihydro-pyrazol-3-one (4-aminophenazone) and 5-amino-3-methyl-1-phenyl$1 \mathrm{H}$-pyrazole-4-carbonitrile in absolute ethanol at reflux temperature for $8 \mathrm{~h}$ to give isoindoline-1,3-dione derivatives 10a-c. The structure of compounds $10 a-c$ was investigated by elemental and spectral analyses. The IR spectrum of 10c revealed a $\mathrm{C} \equiv \mathrm{N}$ stretching band at $\bar{v} 2212 \mathrm{~cm}^{-1}$. The ${ }^{1} \mathrm{H}-\mathrm{NMR}$ spectrum of 10b exhibited three singlet peaks due to two $\mathrm{CH}_{3}$ and $\mathrm{N}-\mathrm{CH}_{3}$ protons at $\delta 2.1,2.5$ and 2.63, respectively. Moreover, ${ }^{13} \mathrm{C}$-NMR spectrum of $\mathbf{1 0 c}$ showed a peak at $\delta 115.04$ corresponding to $\mathrm{C} \equiv \mathrm{N}$. 
Compounds 11a-c were prepared by the reaction of 2-(4-acetyl-phenyl)-isoindoline-1,3-dione (9) with $o$-amino derivatives namely, $o$-phenylenediamine, $o$-aminophenol and $o$-aminothiophenol in refluxing absolute ethanol containing few drops of glacial acetic acid yielding 11a-c in good yields. Spectroscopic data (IR, ${ }^{1} \mathrm{H}-\mathrm{NMR},{ }^{13} \mathrm{C}-\mathrm{NMR}$ and MS) and elemental analysis of compounds $\mathbf{1 1 a}-\mathbf{c}$ confirmed their structures. The ${ }^{1} \mathrm{H}-\mathrm{NMR}$ spectra of 11a-c exhibited $\mathrm{D}_{2} \mathrm{O}$ exchangeable singlet peaks at $\delta 3.35-4.45$ due to the $\mathrm{NH}$ proton, confirming that $\mathbf{1 1 a}-\mathbf{c}$ exists as cyclic benzimidazole, dihydrobenzoxazole and dihydrobenzothiazole with isoindoline-1,3-dione. Another $\mathrm{NH}$ proton appeared in 11a at $\delta 7.65$ corresponding to a benzimidazole that was exchanged with $\mathrm{D}_{2} \mathrm{O}$ (Scheme 1).

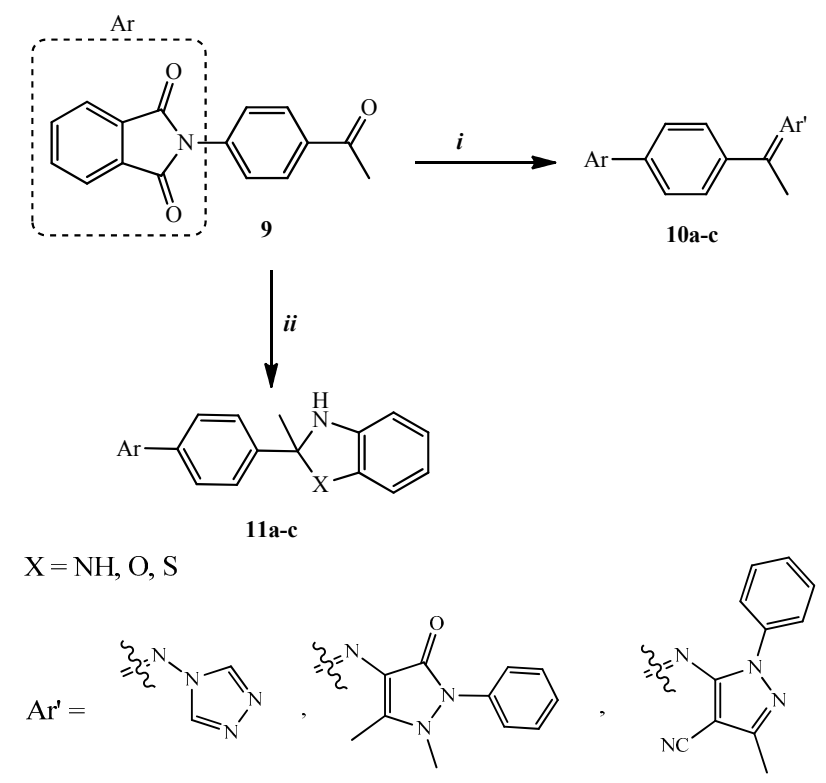

Scheme 1. Synthesis of compounds 10a-c and compound 11a-c. Reagents and conditions: (i) $\mathrm{Ar}^{\prime} \mathrm{NH}_{2}$, absolute ethanol, reflux, $8 \mathrm{~h},(32 \%-44 \%)$; (ii) $o$-phenylenediamine, $o$-aminophenol or $o$-aminothiophenol, absolute ethanol/glacial acetic acid, reflux, $12 \mathrm{~h},(26 \%-46 \%)$.

Treatment of 9 with excess hydrazine hydrate $99 \%$ in dioxane at reflux temperature afforded 2-[4-(1-hydrazonoethyl)phenyl]isoindoline-1,3-dione (12, 45\% yield). All collected data for compound 12 were in accord with the assumed structure. Thus, the absence of $\mathrm{C}=\mathrm{O}$ group of the parent 9 and the observation of forked peak at $\bar{v} 3317$ and $3235 \mathrm{~cm}^{-1}$ corresponding $\mathrm{NH}_{2}$ group in IR spectrum of 12 confirmed its structure. Further the ${ }^{1} \mathrm{H}-\mathrm{NMR}$ spectrum of $\mathbf{1 2}$ showed $\mathrm{D}_{2} \mathrm{O}$ exchangeable protons at $\delta 5.79$ corresponding to $\mathrm{NH}_{2}$ protons. Moreover, the absence of the $\mathrm{C}=\mathrm{O}$ observed in the starting material $\mathbf{9}$ in ${ }^{13} \mathrm{C}$-NMR spectrum of $\mathbf{1 2}$ confirmed the predicted structure of $\mathbf{1 2}$.

Compound 12 was treated with isocyanate and/or isothiocyanate derivatives, e.g., $p$-chlorophenylisocyanate, ethylisothiocyanate and phenylisothiocyanate in dioxane at reflux temperature to provide the corresponding oxo(or thioxo)triazole derivatives 13a-c rather than semicarbazide or thiosemicarbazide analogues $\mathbf{A}$. The structures of compounds $13 \mathbf{a}-\mathbf{c}$ were investigated by elemental and spectral analyses. The ${ }^{13} \mathrm{C}-\mathrm{NMR}$ spectra of $\mathbf{1 3 a}-\mathbf{c}$ revealed peaks at $\delta 70.80-90.03$ due to the $\mathrm{CH}_{3}-\mathrm{C}$ of the triazole ring which is not present in the open form $\mathbf{A}$.

The triazole ring was also assembled via reaction of compound $\mathbf{9}$ with a thiosemicarbazide derivative yielding 14 rather than the open form B. The structure of compound $\mathbf{1 4}$ was established through, spectroscopic and elemental analyses data. The ${ }^{13} \mathrm{C}$-NMR spectrum of $\mathbf{1 4}$ showed the presence of the 
$\mathrm{CH}_{3}-\mathrm{C}$ moiety of the thioxotriazole ring at $\delta 66.80$ that was absent in the starting material 9 or in the thiosemicarbazide derivative $\mathbf{B}$, thus confirming the putative structure $\mathbf{1 4}$.

Treatment of 9 with a molar equivalent of benzohydrazide derivative in dioxane at reflux temperature for $7 \mathrm{~h}$, gave $N^{\prime}$-\{1-[4-(1,3-dioxoindolin-2-yl)phenyl]ethylidene $\}$ benzohydrazide (15) as a yellow solid in $48 \%$ yield. The structure of compound 15 was confirmed by elemental and spectroscopic analyses. The IR spectrum of 15 showed NH stretching at $\bar{v} 3330 \mathrm{~cm}^{-1}$ apart from a $\mathrm{C}=\mathrm{O}$ band at $\bar{v} 1672 \mathrm{~cm}^{-1}$. Moreover, the ${ }^{1} \mathrm{H}-\mathrm{NMR}$ spectrum of $\mathbf{1 5}$ revealed the presence of two singlet peaks at $\delta 2.56$ and 2.64 due to the syn and anti $\mathrm{CH}_{3}$ groups around the $\mathrm{CH}_{3}-\mathrm{C}=\mathrm{N}$ double bond. Also, in the mass spectrum of 15 the molecular ion $\left[\mathrm{M}^{+}\right]\left(\mathrm{m} / z\right.$ 383) corresponding to the formula $\mathrm{C}_{23} \mathrm{H}_{17} \mathrm{~N}_{3} \mathrm{O}_{3}$ was observed (Scheme 2).

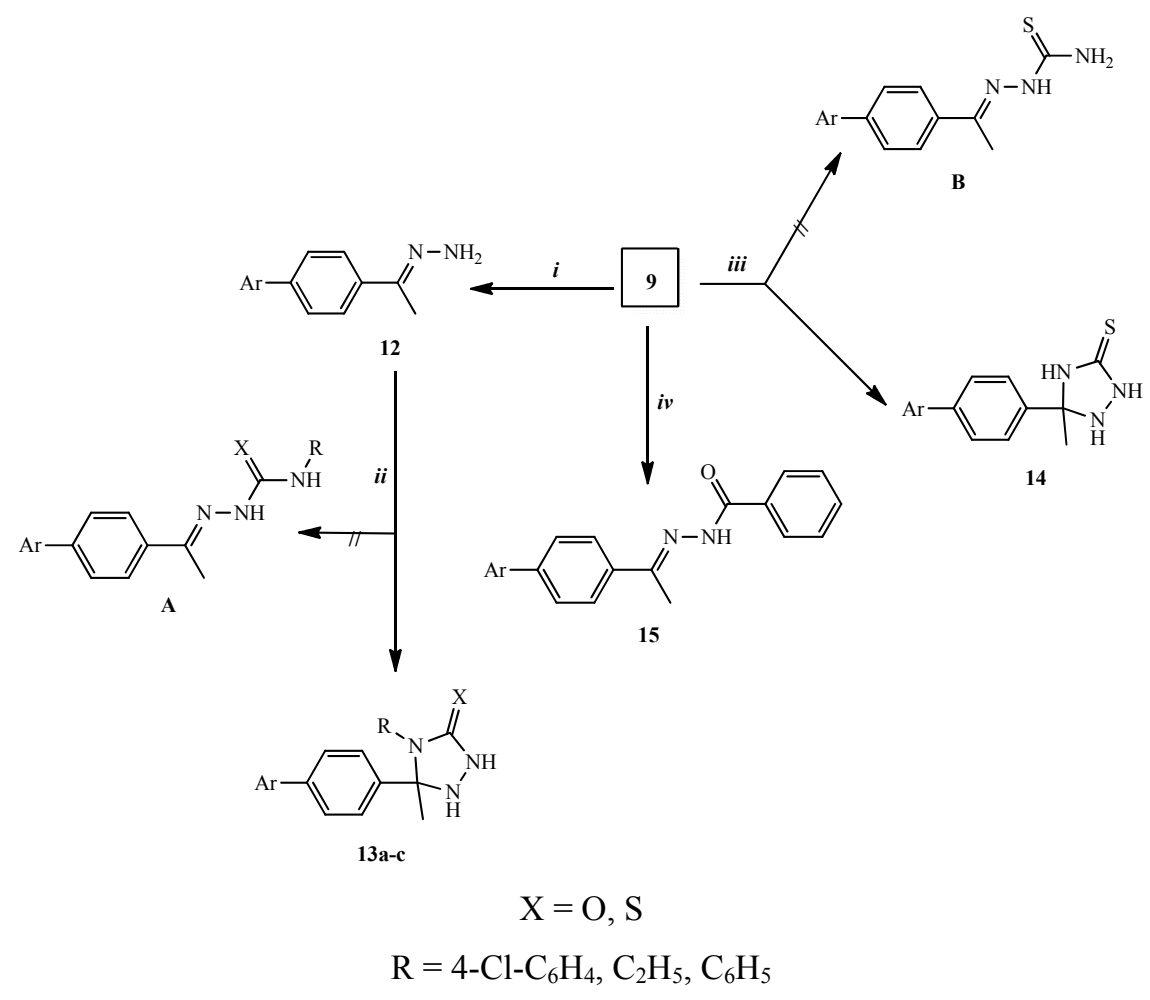

Scheme 2. Synthesis of triazole derivatives 13a-c, 14 and compound 15. Reagents and conditions: (i) $\mathrm{NH}_{2} \mathrm{NH}_{2}$, dioxane, reflux, $2 \mathrm{~h}$, (24\%); (ii) RNCX, dioxane, reflux, $5 \mathrm{~h}$, (39\%-47\%); (iii) $\mathrm{NH}_{2} \mathrm{NHCSNH}_{2}$, dioxane, reflux, 3 h, (33\%); (iv) $\mathrm{PhCONHNH}_{2}$, dioxane, reflux, $7 \mathrm{~h},(48 \%)$.

Introducing a diazole moiety to compound 16 was achieved by heating 9 with an equimolar quantity of ethylenediamine in refluxing dioxane for $4 \mathrm{~h}$. The IR spectrum of $\mathbf{1 6}$ revealed the absence of the $\mathrm{C}=\mathrm{O}$ group of the parent compound 9. Moreover, aromatization of the diazole ring was confirmed from the ${ }^{1} \mathrm{H}-\mathrm{NMR}$ spectrum that showed two $\mathrm{CH}$ diazole ring protons as doublets at $\delta 6.56$ and 7.66 with a coupling constant of $8.4 \mathrm{~Hz}$. The mass spectrum of $\mathbf{1 6}$ exhibited a molecular ion peak $\left[\mathrm{M}^{+}\right]$at $(\mathrm{m} / z$ 303) confirming its molecular formula $\mathrm{C}_{18} \mathrm{H}_{13} \mathrm{~N}_{3} \mathrm{O}_{2}$.

Treatment of 9 with hydrochloride salt of phenylhydrazine, $p$-methanesulfonylphenylhydrazine or $p$-aminosulfonylphenylhydrazine in a molar ratio (1:1) in refluxing absolute ethanol gave $\mathbf{1 7} \mathbf{a}-\mathbf{c}$ in excellent yields. All data for compounds 17a-c were consistent with the proposed structures. Thus, the absence of the $\mathrm{C}=\mathrm{O}$ group of the parent 9 in IR spectra of $17 \mathbf{a}-\mathbf{c}$ and the appearance of $\mathrm{NH}$ (in $\mathbf{1 7} \mathbf{a}-\mathbf{c}$ ) 
and $\mathrm{NH}_{2}$ (in 17c) stretching bands at $\bar{v} 3428-3258 \mathrm{~cm}^{-1}$ confirmed the structures of 17a-c. Moreover, the syn and anti $\mathrm{CH}_{3}$ protons were observed at $\delta 2.30-2.36$ and 2.51-2.63. Further, the NH proton singlet was recorded at $\delta 9.87-9.98$ that was exchangeable with $\mathrm{D}_{2} \mathrm{O}$ confirmed structure of the $\mathbf{1 7 a}-\mathbf{c}$ (Scheme 3).

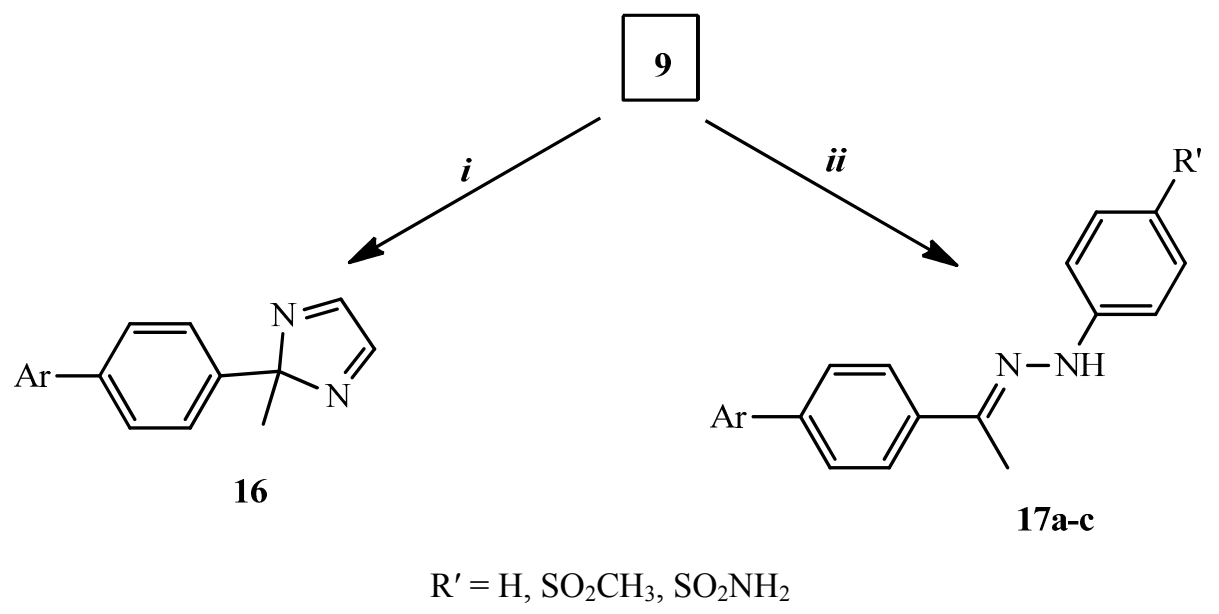

Scheme 3. Synthesis of compounds 16 and $17 \mathbf{a}-\mathbf{c}$. Reagents and conditions: (i) $\mathrm{NH}_{2} \mathrm{CH}_{2} \mathrm{CH}_{2} \mathrm{NH}_{2}$, dioxane, reflux, 4 h, (26\%); (ii) 4-R'PhNHNH $2 . \mathrm{HCl}$, absolute ethanol, reflux, 5-8 h, (49\%-52\%).

\subsection{Biological Evaluation}

\subsubsection{Anti-Microbial Activity}

Different species of microorganisms have varying degrees of susceptibility to antimicrobials. Further, the pathogenic microbes may develop drug resistance to a particular type of antimicrobial agent on prolonged use. Hence, the antimicrobial sensitivity tests are very useful to determine the level of antimicrobial activity of a particular chemical compound on certain pathogenic microorganisms using agar well diffusion method, (Figure 2).

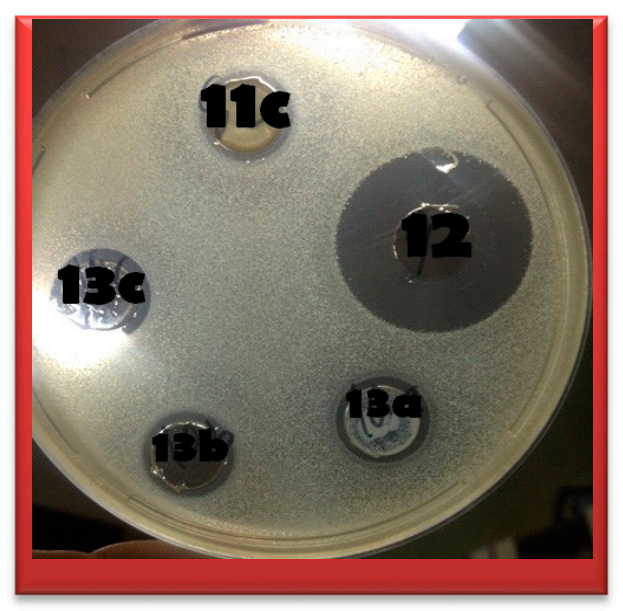

Figure 2. Examples of some activities for compounds 11c, 12, 13a, 13b and 13c against Bacillus subtilis. 
Table 1. The zone of inhibition (mm) for test compounds *\#.

\begin{tabular}{|c|c|c|c|c|c|c|c|c|c|c|c|}
\hline & \multicolumn{3}{|c|}{ Gram Positive Rods } & \multicolumn{3}{|c|}{ Gram Positive Cocci } & \multicolumn{4}{|c|}{ Gram Negative Rods } & \multirow{2}{*}{$\begin{array}{c}\text { Yeast } \\
\text { Candida } \\
\text { albicans }\end{array}$} \\
\hline & $\begin{array}{c}\text { Bacillus } \\
\text { subtilis } \\
\end{array}$ & $\begin{array}{c}\text { Listeria inocua } \\
\text { LMG } 2710 \\
\end{array}$ & $\begin{array}{c}\text { Mycobacterium } \\
\text { pheli }\end{array}$ & $\begin{array}{c}\text { Enterococcus } \\
\text { faecalis }\end{array}$ & $\begin{array}{c}\text { Sarcina } \\
\text { lutea }\end{array}$ & $\begin{array}{c}\text { Staphylococcus aureus } \\
\text { LMG } 3242 \\
\end{array}$ & $\begin{array}{c}\text { Escherichia coli } \\
\text { ATCC } 25922 \\
\end{array}$ & $\begin{array}{c}\text { Escherichia coli } \\
\text { ATCC } 5087 \\
\end{array}$ & $\begin{array}{c}\text { Psedomonas } \\
\text { aeruginosa }\end{array}$ & $\begin{array}{l}\text { Proteus } \\
\text { vulgaris }\end{array}$ & \\
\hline $10 \mathrm{a}$ & 13 & - & - & - & - & 14 & - & - & - & - & 14 \\
\hline $10 \mathrm{c}$ & - & 15 & 15 & - & - & - & - & - & 12 & - & 14 \\
\hline $11 \mathrm{a}$ & 15 & 13 & 13 & 16 & - & 14.5 & 13 & - & 13 & - & 14 \\
\hline $11 \mathrm{~b}$ & 15 & 13 & 13 & 16.5 & - & 14 & 12 & - & 12 & - & 13 \\
\hline 12 & 26 & 17 & 23 & 17.5 & 25 & 16 & 17 & 17 & 25 & - & 21 \\
\hline $13 a$ & 13 & 14 & - & 15.5 & - & 13 & - & - & - & - & - \\
\hline $13 b$ & 13 & 15.5 & 13 & 14 & 14 & 13 & - & - & - & - & 14 \\
\hline $13 c$ & 14 & 16 & 16 & 13.5 & 17.5 & 13 & - & - & 13 & - & 13 \\
\hline 14 & 16 & 15 & 15.5 & 15 & 18 & - & - & - & 13 & 12 & 14 \\
\hline 15 & 13 & - & - & 13.5 & - & - & - & - & 11 & - & 17.5 \\
\hline $\mathbf{A M P}^{(\mathrm{a})}$ & 22 & 30 & 42 & 30 & 54 & 31 & 38 & 44 & - & - & - \\
\hline $\operatorname{CTX}^{(\mathbf{b})}$ & 25 & 21 & 40 & 22 & 48 & 25 & 42 & 52 & 30 & 31 & - \\
\hline $\mathbf{C N}^{(\mathrm{c})}$ & 28 & 31 & 36 & 20 & 40 & 24 & 34 & 40 & 36 & 39 & - \\
\hline FLU ${ }^{(d)}$ & - & - & - & - & - & - & - & - & - & - & 40 \\
\hline TIO $^{(\mathrm{e})}$ & - & - & - & - & - & - & - & - & - & - & 36 \\
\hline
\end{tabular}

* All synthesized compounds and control anti-microbial were dissolved in DMSO to give a final concentration of $10 \mathrm{mg} / \mathrm{mL}$ and then a $60 \mu \mathrm{L}$ of each was inoculated into cup in agar media. ${ }^{\#}$ Incubation temperature was $37 \pm 1{ }^{\circ} \mathrm{C}$ for $24 \mathrm{~h} .{ }^{(a)} \mathrm{AMP}$ : Ampicillin; ${ }^{(b)} \mathrm{CTX}$ : Cefotaxime; ${ }^{(\mathrm{c})} \mathrm{CN}$ : Gentamicin; ${ }^{(\mathrm{d})}$ FLU: Fluconazole; ${ }^{\left({ }^{(e)}\right.} \mathrm{TIO}$ : Tioconazole. 
Table 2. MIC of samples against different microorganisms $(\mu \mathrm{g} / \mathrm{mL}) * \#$.

\begin{tabular}{|c|c|c|c|c|c|c|c|c|c|c|c|c|c|c|}
\hline $\begin{array}{l}\text { Compound } \\
\text { No. }\end{array}$ & $\begin{array}{l}\text { Proteus } \\
\text { vulgaris }\end{array}$ & $\begin{array}{c}\text { Salmonella } \\
\text { typhi }\end{array}$ & $\begin{array}{c}\text { Pseudomonas } \\
\text { aeruginosa } \\
9027 \\
\end{array}$ & $\begin{array}{l}\text { E. coli } \\
25927\end{array}$ & $\begin{array}{c}\text { E. coli } \\
5087\end{array}$ & $\begin{array}{c}\text { Sarcina } \\
\text { lutea }\end{array}$ & $\begin{array}{l}\text { Enterococcus } \\
\text { faecalis OS4 }\end{array}$ & $\begin{array}{c}\text { Mycobacterium } \\
\text { pheli }\end{array}$ & $\begin{array}{c}\text { Lactobacillus } \\
\text { sakei } \\
\text { LMG } 2313 \\
\end{array}$ & $\begin{array}{l}\text { Bacillus } \\
\text { subtilis }\end{array}$ & $\begin{array}{c}\text { Listeria } \\
\text { innocua } \\
\text { LMG } 2710 \\
\end{array}$ & $\begin{array}{c}\text { Staphylococcus } \\
\text { aureus } \\
\text { LMG } 3242 \\
\end{array}$ & $\begin{array}{c}\text { Staphylococcus } \\
\text { aureus } \\
\text { ATCC } 43300 \\
\end{array}$ & $\begin{array}{c}\text { Candida } \\
\text { albicans } \\
\text { ATCC } 60931 \\
\end{array}$ \\
\hline $10 \mathrm{~b}$ & na & na & na & na & na & na & na & na & na & na & na & na & na & na \\
\hline 11a & na & na & na & na & na & na & 100 & 50 & 50 & na & 25 & 50 & na & na \\
\hline $11 b$ & na & na & na & na & na & na & na & na & 50 & na & na & na & na & na \\
\hline $11 \mathrm{c}$ & na & na & na & na & na & na & na & na & na & na & 100 & na & na & 100 \\
\hline 12 & na & na & 100 & na & na & 50 & 50 & 25 & 200 & 25 & 100 & na & na & 100 \\
\hline $13 \mathrm{c}$ & 200 & na & 200 & 200 & 200 & na & 200 & na & 200 & 200 & 200 & 200 & 200 & na \\
\hline 14 & na & na & na & na & na & na & na & na & na & na & na & na & na & na \\
\hline 16 & na & na & na & na & na & na & na & na & na & na & na & na & na & na \\
\hline $17 \mathrm{a}$ & na & na & na & na & na & na & na & na & na & na & na & na & na & 25 \\
\hline
\end{tabular}

* All tested compounds and controls were used in a final concentration ranging from $(200 \mu \mathrm{g} / \mathrm{mL}-0.7 \mu \mathrm{g} / \mathrm{mL}) .{ }^{*}$ Incubation temperature was $37 \pm 1{ }^{\circ} \mathrm{C}$ for $24 \mathrm{~h}$. na: (not active $>200$ unit). 
Candida albicans, Listeria innocua, Bacillus subtilis and Enterococcus faecalis were the most susceptible microorganisms toward the majority of our synthetic chemical compounds, while Escherichia coli, Proteus vulgaris and Sarcine lutea were the most resistant bacteria. Based on the antimicrobial sensitivity determinations, all of our compounds showed marked activity against at least two out of the six tested Gram positive bacteria, where the order of activity was as follows; compound 12 showed the highest activity followed by 13c, 13b, 14, (11a = 11b), 10b, 13a, 17a, $(16=17 \mathbf{b}), 11 \mathrm{c}$, 10c, 17c, 15 and finally 10a. Compounds 12, 13c and 13b were able to inhibit all six tested Gram positive bacteria. Only compound $\mathbf{1 2}$ showed marked activity against Bacillus subtilis where the percentage activities were $133 \%, 106 \%$ and $88.8 \%$ when compared with the standard antibiotics ampicillin, cefotaxime and gentamicin, respectively. Activity against Gram negative bacteria was weak, and only compound 12 was able to inhibit 3/4 tested organisms. Compound 12 also showed its highest activities in Gram negative bacteria against Pseudomonas aeruginosa where the percentage activities were $75 \%$ and $57.6 \%$ when compared with the standard antibiotics cefotaxime and gentamicin, respectively. The order of activity against Gram negative bacteria was as follows; $12,11 \mathrm{a}, 14,11 \mathrm{~b}, 17 \mathbf{a},(11 \mathrm{c}=13 \mathrm{c}=17 \mathrm{c})$, $(10 c=16=17 b)$ and finally 15 while compounds 10b, 13a, 13b and 10a failed to show any activity against any of the tested Gram negative bacteria at the tested concentrations. All compounds apart from 13a showed activity against Candida albicans in the following order of activity: 12, 11c, 16, 15, $17 \mathbf{a}, 10 \mathrm{~b}, 17 \mathrm{c},(10 \mathrm{a}=10=11 \mathrm{a}=13 \mathrm{~b}=14),(11 \mathrm{~b}=13 \mathrm{c})$ and $17 \mathbf{b}($ Tables 1 and 2$)$.

\subsubsection{Anti-Oxidant Activity}

Oxygen radical absorbance capacity (ORAC) is the ability of compounds to scavenge free peroxy radicals in vitro. While $\mathbf{1 0 a}, \mathbf{1 0 c}$ and $\mathbf{1 6}$ activities were below detection limits $(<0.1)$, $\mathbf{1 3 b}$ and $\mathbf{1 3 c}$ were $18 \times(18.385 \pm 0.857)$ and $14 \times$ times $(13.506 \pm 0.819)$ more active than Trolox, the hydrophilic derivative of vitamin $\mathrm{E}$ (Table 3 ).

Table 3. Oxygen radical absorbance capacity given as ratio between compound and Trolox on an equimolar basis. Data are expressed as mean $\pm \operatorname{SD}(n=4)$.

\begin{tabular}{cc}
\hline Compound & ORAC (Compound/Trolox) \\
\hline $\mathbf{1 0 a}$ & $<0.1$ \\
$\mathbf{1 0 b}$ & $0.112 \pm 0.007$ \\
$\mathbf{1 0 c}$ & $<0.1$ \\
$\mathbf{1 1 a}$ & $0.751 \pm 0.081$ \\
$\mathbf{1 1 b}$ & $0.116 \pm 0.004$ \\
$\mathbf{1 1 c}$ & $0.183 \pm 0.01$ \\
$\mathbf{1 2}$ & $8.116 \pm 0.343$ \\
$\mathbf{1 3 a}$ & $1.169 \pm 0.118$ \\
$\mathbf{1 3 b}$ & $18.385 \pm 0.857$ \\
$\mathbf{1 3 c}$ & $13.506 \pm 0.819$ \\
$\mathbf{1 4}$ & $1.511 \pm 0.045$ \\
$\mathbf{1 5}$ & $0.192 \pm 0.005$ \\
$\mathbf{1 6}$ & $<0.1$ \\
$\mathbf{1 7 a}$ & $1.839 \pm 0.035$ \\
$\mathbf{1 7 b}$ & $0.129 \pm 0.005$ \\
$\mathbf{1 7} \mathbf{c}$ & $0.374 \pm 0.007$ \\
\hline
\end{tabular}




\subsubsection{Anti-Inflammatory Activity}

The in vitro anti-inflammatory properties of the phthalimide derivatives were studied using ELISA in pretreated Human Umbilical Vein Endothelial Cells (HUVEC) where these compounds could inhibit $\mathrm{NF}-\kappa \mathrm{B}$. E-selectin (ELAM) expression was induced by TNF $\alpha$, which is indicative of NF- $\mathrm{BB}$ activation. The observed reduction of ELAM expression on treatment of HUVECs with $30 \mu \mathrm{M}$ or $50 \mu \mathrm{M}$ of phthalimide derivatives was significant only for $\mathbf{1 7} \mathbf{c}-p$-aminosulfone derivative- (decrease of $32 \%$ ). Slight inhibition of ELAM expression and also cell viability was measured for 10b, 11c, 12, 13a, 13b, 13c, 14, 15, 17b. The results showed confirmed that the NF- $\kappa B$ pathway was targeted by the phthalimide derivatives (Figure 3).

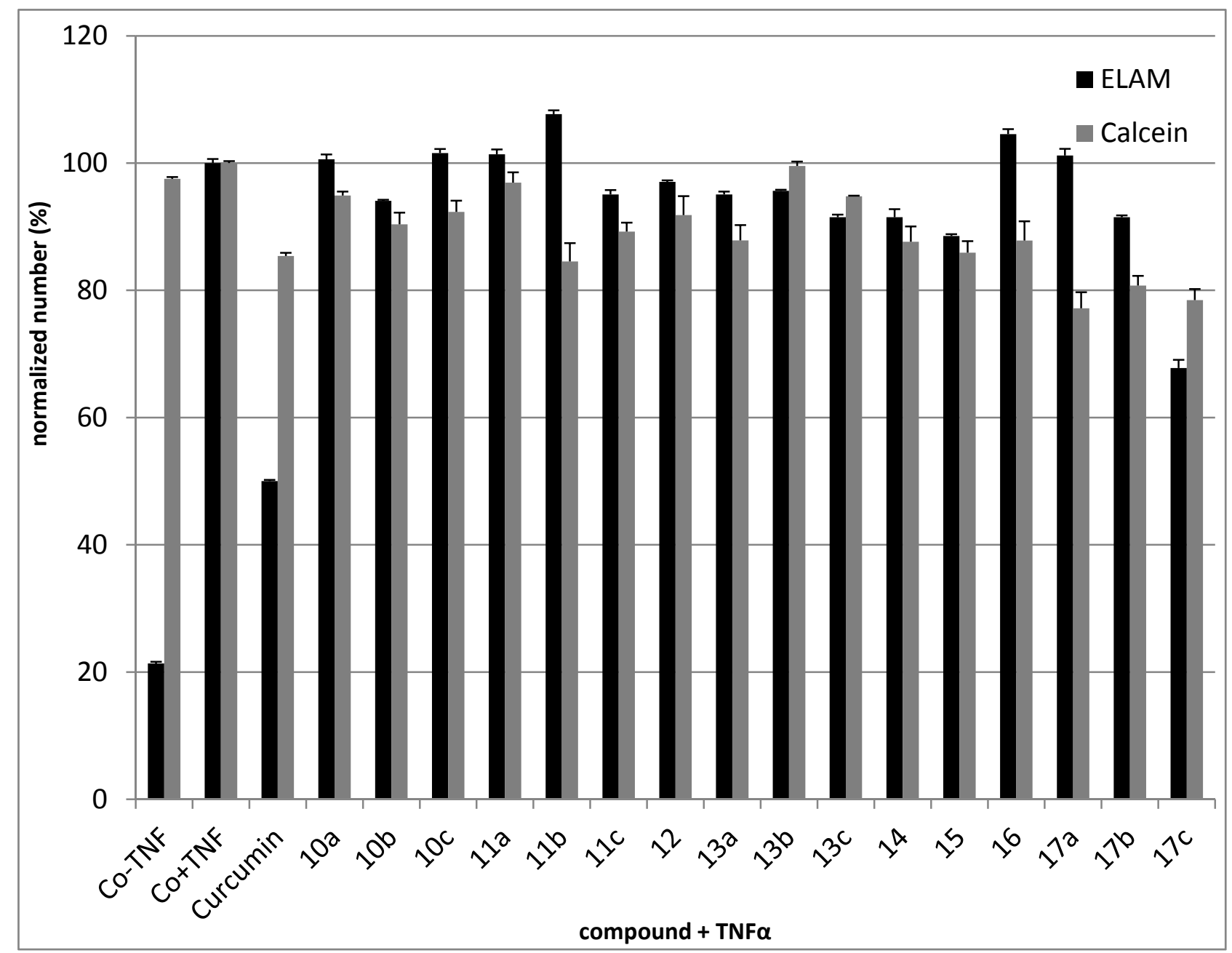

Figure 3. E-Selectin (ELAM) expression in TNF $\alpha$-induced HUVECs compared to cytotoxicity determined by Calcein AM. Curcumin $(10 \mu \mathrm{M})$ was used as a positive control.

$1 \times 10^{4} \mathrm{HUVECs} /$ well were seeded into 96-well plates and grown to confluence. $50 \mu \mathrm{M}$ of phthalimide derivatives were added $30 \mathrm{~min}$ prior to application of $10 \mathrm{ng} / \mathrm{mL} \mathrm{TNF} \alpha$ for another $4 \mathrm{~h}$. The cells were then fixed and ELAM levels analysed by ELISA. At the same time, the compounds were analysed by Calcein AM assay to monitor non-specific substance toxicity. 


\subsubsection{Cytotoxic Activity}

Sixteen phthalimide derivatives $(10 a-c, 11 a-c, 12,13 a-c, 14,15,16,17 \mathbf{a}-\mathbf{c})$ were tested for cytotoxicity in three different cancer cell lines derived from various tumours (CEM, MCF7, HeLa), normal human fibroblasts (BJ) and human umbilical vein endothelial cells (HUVEC). Treatment of cancer cell lines and fibroblasts with tested compounds for $72 \mathrm{~h}$ resulted in no loss of viability (data not shown). After $24 \mathrm{~h}$, the phthalimide derivatives showed no cytotoxicity towards HUVECs (data not shown).

\subsection{Molecular Modeling}

Compound 17c had the highest anti-inflammatory effects of all tested compounds. Given that the most important enzymatic system in inflammation is the cyclooxygenase system [20], a molecular modelling study was carried out to investigate the binding conformation for $\mathbf{1 7} \mathbf{c}$ and the active binding site of the COX-2 enzyme. The molecular docking study was done using the crystal structure of COX-2 (protein database [PDB] entry: ID 3LN1] [21], with compound 17c (containing COX-2 pharmacophore moiety $-\mathrm{SO}_{2} \mathrm{NH}_{2}$ and celecoxib (6) as the reference ligand. The modelling software which was used for this study was the MOE version 2008.10 (Molecular Operating Environment-Montreal, QC, Canada) [22].

Celecoxib as the ligand used in this study, was flexibly docked to the binding site of the COX-2 enzyme, and the docking conformation that was represented by the lowest energy score value was selected. The newly synthesized compound $\mathbf{1 7} \mathbf{c}$ was docked. The docking study showed that $\mathbf{1 7} \mathbf{c}$ occupied the COX-2 binding site compared to celecoxib (6), (Figure 4).

The binding energy for compound $17 \mathrm{c}$ was $-17.89 \mathrm{kcal} / \mathrm{mol}$ compared to $-17.27 \mathrm{kcal} / \mathrm{mol}$ for celecoxib (6). Moreover, compound 17c exhibited four hydrogen bonding interactions with Tyr341 $(\mathrm{C}=\mathrm{O}), \operatorname{Arg} 106(\mathrm{C}=\mathrm{O}), \operatorname{Arg} 499(\mathrm{~S}=\mathrm{O})$, and $\mathrm{Gln} 178(\mathrm{NH})$ and amino acids with hydrogen bond lengths $(2.75,2.77,2.96$, and $2.21 \AA$, respectively), (Table 4 and Figure 4$)$.

Table 4. Molecular modelling data for compound 17c and celecoxib (6) during docking in the COX-2 (PDB: ID3LN1) active site.

\begin{tabular}{ccccc}
\hline Compound No. & E-Refine (kcal/mol) & No. of Hydrogen Bonds & Hydrogen Bonding Residues & Distance $(\AA)$ \\
\hline \multirow{3}{*}{$\mathbf{1 7 c}$} & \multirow{2}{*}{-17.89} & 4 & $\operatorname{Tyr} 341(\mathrm{C}=\mathrm{O})$ & 2.75 \\
& & & $\operatorname{Arg} 106(\mathrm{C}=\mathrm{O})$ & 2.77 \\
& & & $\operatorname{Arg} 499(\mathrm{~S}=\mathrm{O})$ & 2.96 \\
\hline \multirow{3}{*}{ Celecoxib (6) } & \multirow{2}{*}{-17.27} & 2 & $\mathrm{Gln} 178(\mathrm{NH})$ & 2.21 \\
& & & $\operatorname{Leu338}(\mathrm{NH})$ & 2.63 \\
& & & $\mathrm{Gln} 178(\mathrm{NH})$ & 2.55 \\
\hline
\end{tabular}

\section{Experimental Section}

\subsection{General Information}

Melting points were determined on an Electrothermal digital melting point apparatus and are uncorrected. (IR spectra were recorded on an R 435 spectrophotometer (Middlton, Madison West, WI, USA) and values were reported in $\mathrm{cm}^{-1} .{ }^{1} \mathrm{H}-\mathrm{NMR}$ and ${ }^{13} \mathrm{C}-\mathrm{NMR}$ were carried out on Bruker Advance III $400 \mathrm{MHz}$ spectrophotometer (Bruker BioSpin AG, Fällanden, Switzerland) for ${ }^{1} \mathrm{H}$ and $100 \mathrm{MHz}$ for 
${ }^{13} \mathrm{C}$ with BBFO Smart Probe and Bruker 400 AEON Nitrogen-Free Magnet, using TMS as an internal standard and chemical shifts were recorded in ppm on $\delta$ scale, Faculty of Pharmacy, Beni Suef University, Egypt. The electron impact (EI) mass spectra were recorded on a Hewlett Packard 5988 spectrometer (Palo Alto, CA, USA), Microanalyses for C, H and N were carried out on Perkin-Elmer 2400 analyzer (Perkin-Elmer, Norwalk, CT, USA) at the Micro analytical unit of Cairo University, Egypt, and all compounds were within $\pm 0.4 \%$ of the theoretical values. Thin-layer chromatography (TLC) was performed on Merck (Darmstadt, Germany ) TLC aluminium sheets silica gel $60 \mathrm{~F}_{254}$ with detection by UV quenching at $254 \mathrm{~nm}$ to follow the course of reactions and to check the purity of products. All reagents and solvents were purified and dried by standard techniques.

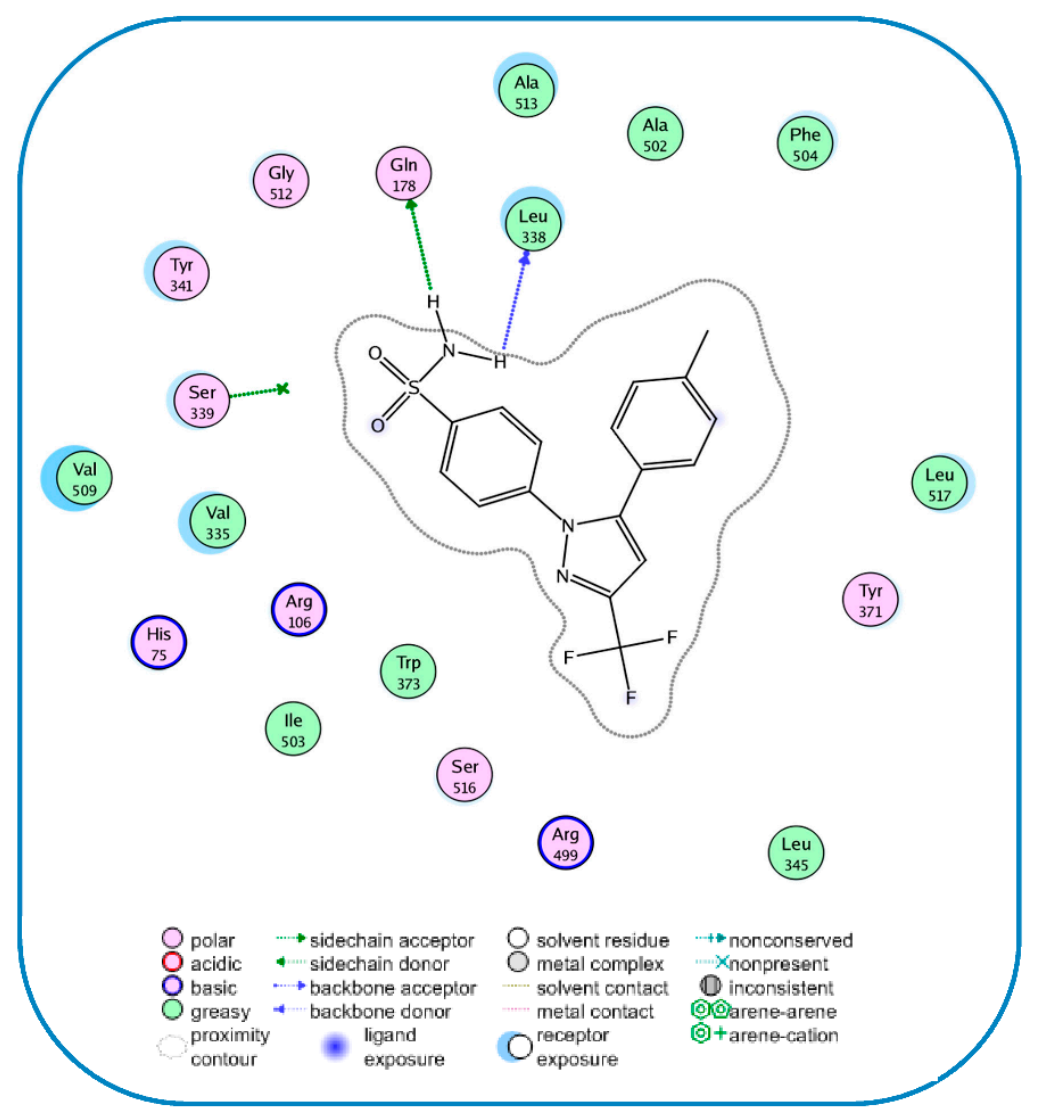

(a)

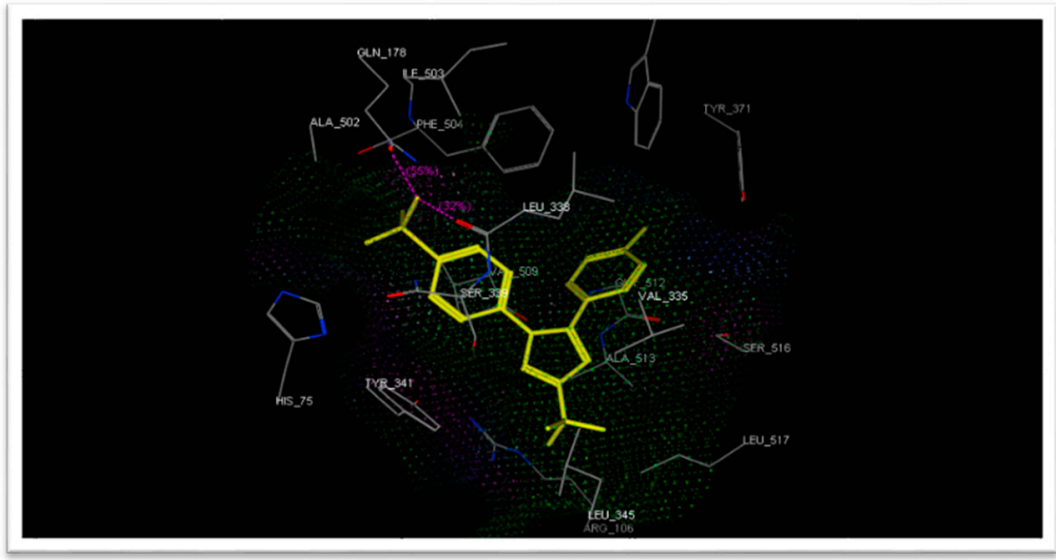

(b)

Figure 4. Cont. 


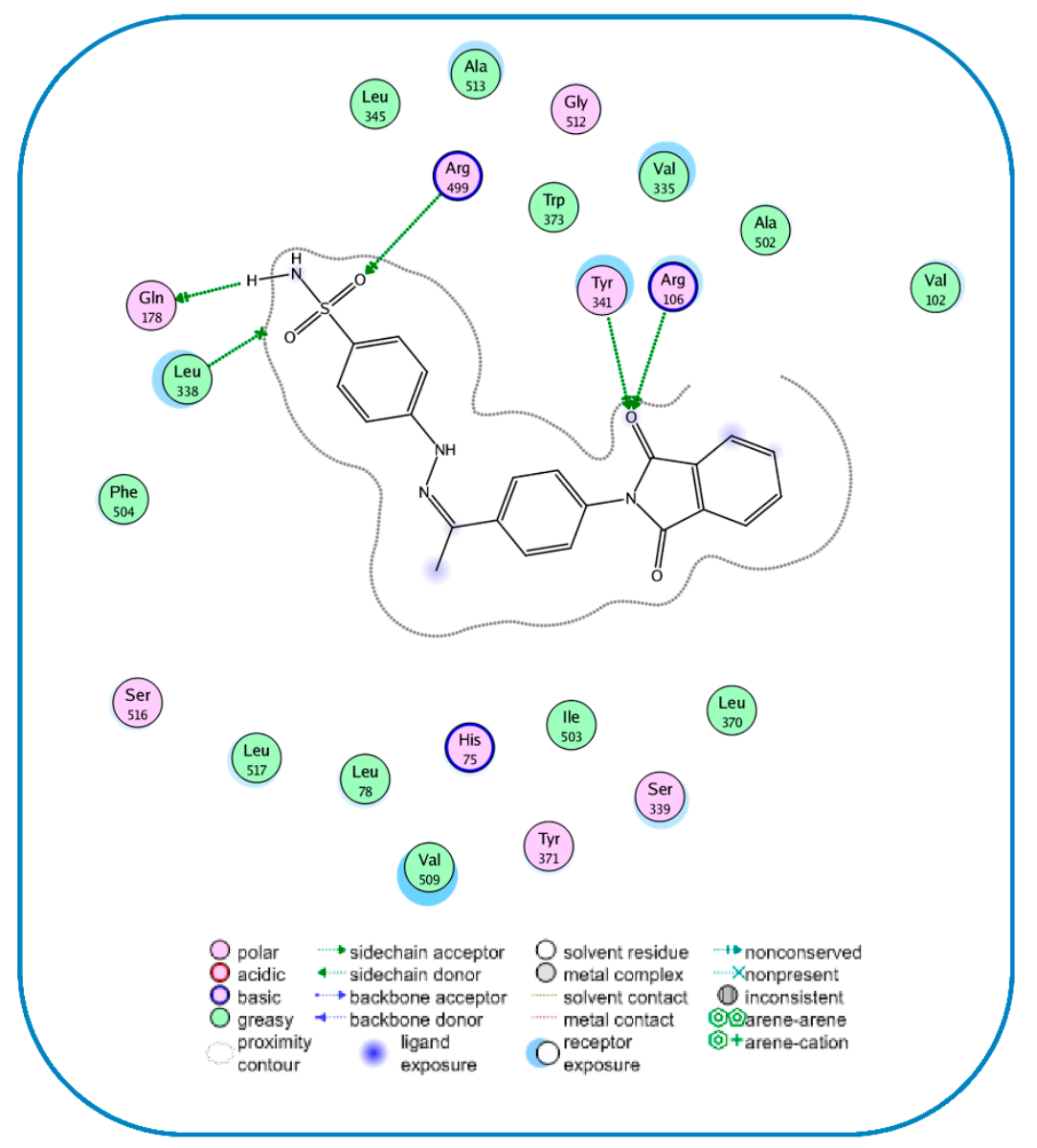

(c)

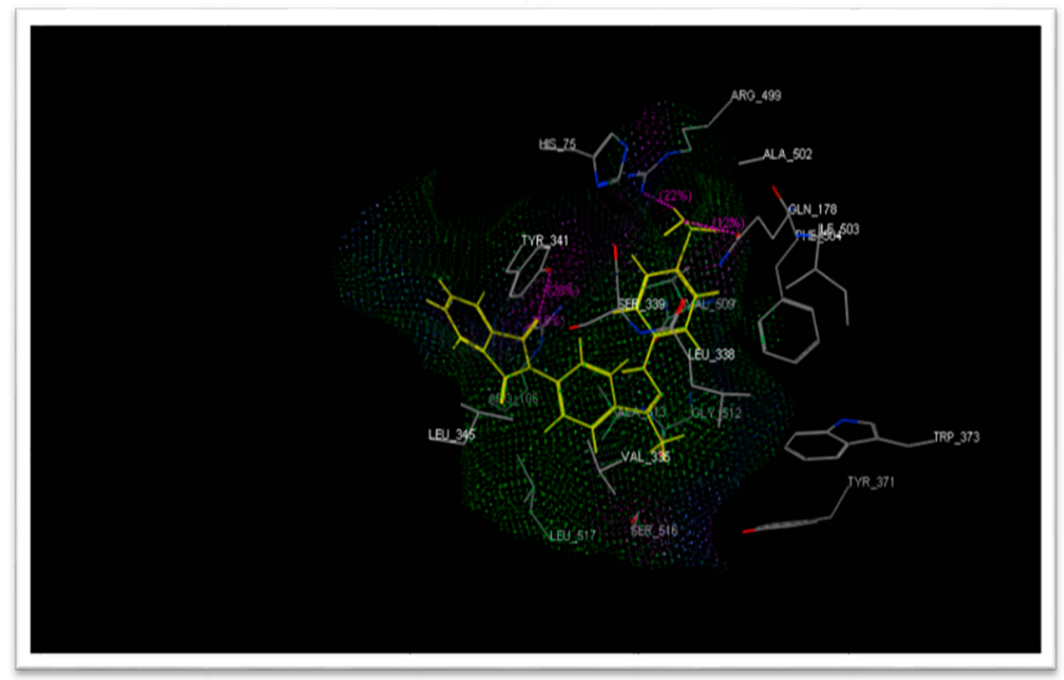

(d)

Figure 4. Binding of celecoxib (6) and the most active compound 17c inside COX-2 active site. (a) 2D Interaction for binding of celecoxib (6) inside COX-2 active site, the most important amino acids are shown together with their respective numbers; (b) 3D interaction of celecoxib (6); (c) 2D interaction for binding of the most active compound 17c inside COX-2 active site, the most important amino acids are shown together with their respective numbers; (d) 3D interaction of $\mathbf{1 7}$. 


\subsubsection{General Procedure for the Synthesis of Compounds 10a-c}

A mixture of $9(2.65 \mathrm{~g}, 0.01 \mathrm{~mol})$ and the appropriate primary amine $(0.01 \mathrm{~mol})$ was refluxed in absolute ethanol $(30 \mathrm{~mL})$ for $8 \mathrm{~h}$. The solid separated on hot was filtered, dried and crystallized from dioxane.

(ZE)-2-\{4-[1-(4H-1,2,4-Triazol-4-ylimino)ethyl]phenyl\}isoindoline-1,3-dione (10a). Yield 32\%; m.p. 222-224 ${ }^{\circ} \mathrm{C}$; IR $\left(\mathrm{KBr}, \mathrm{cm}^{-1}\right): 1785$ and 1714 (2C=O, isoindoline-1,3-dione); ${ }^{1} \mathrm{H}-\mathrm{NMR}$ (DMSO- $d_{6}$ ) $\delta 2.63$ (s, 3H, CH3), 7.64-7.89 (m, 2H, Ar-H), 7.94 (s, 2H, Ar-H), 7.99-8.01 (m, 3H, Ar-H), 8.10-8.24 $(\mathrm{m}, 3 \mathrm{H}, \mathrm{Ar}-\mathrm{H}) ;{ }^{13} \mathrm{C}-\mathrm{NMR}\left(\mathrm{DMSO}-d_{6}\right) \delta$ 13.50, 124.03, 124.50, 127.54, 129.24, 131.98, 135.33, 136.28, 136.49, 158.80, 167.13; MS (m/z, \%): $331\left(\mathrm{M}^{+}, 1.77 \%\right), 64(100 \%)$; Anal. Calcd. for $\mathrm{C}_{18} \mathrm{H}_{13} \mathrm{~N}_{5} \mathrm{O}_{2}: \mathrm{C}_{\text {, }}$ $65.25 ; \mathrm{H}, 3.95 ; \mathrm{N}, 21.14$. Found: C, 65.03; H, 4.14; N, 21.30\%.

(ZE)-2-\{4-[1-(1,5-Dimethyl-3-oxo-2-phenyl-2,3-dihydro-1H-pyrazol-4-ylimino)ethyl]phenyl\}isoindoline1,3-dione (10b). Yield 44\%; m.p. 218-220 ${ }^{\circ} \mathrm{C}$; IR $\left(\mathrm{KBr}, \mathrm{cm}^{-1}\right)$ : 1784 and $1714(2 \mathrm{C}=\mathrm{O}$, isoindoline-1,3dione), $1679(\mathrm{C}=\mathrm{O}) ;{ }^{1} \mathrm{H}-\mathrm{NMR}\left(\mathrm{DMSO}-d_{6}\right) \delta 2.1\left(\mathrm{~s}, 3 \mathrm{H}, \mathrm{CH}_{3}\right), 2.50\left(\mathrm{~s}, 3 \mathrm{H}, \mathrm{CH}_{3}\right), 2.63\left(\mathrm{~s}, 3 \mathrm{H}, \mathrm{CH}_{3}\right)$, 7.64-7.89 (m, 3H, Ar-H), 7.95-7.98 (m, 7H, Ar-H), 8.00-8.15 (m, 3H, Ar-H); ${ }^{13} \mathrm{C}-\mathrm{NMR}$ (DMSO- $\left.d_{6}\right)$ $\delta 15.10,16.50,39.32,122.80,123.94,127.29,127.51,128.38,128.80,129.24,132.01,133.29,135.24$, 137.20, 138.08, 150.20, 158.80, 160.70, 167.36; MS (m/z, \%): $450\left(\mathrm{M}^{+}, 2.40 \%\right), 64$ (100\%); Anal. Calcd. for $\mathrm{C}_{27} \mathrm{H}_{22} \mathrm{~N}_{4} \mathrm{O}_{3}$ : C, $71.99 ; \mathrm{H}, 4.92 ; \mathrm{N}, 12.44$. Found: C, 72.13; H, 4.85; N, 12.29\%.

(ZE)-5-\{1-[4-(1,3-Dioxoisoindolin-2-yl)phenyl] ethylidineamino\}-3-methyl-1-phenyl-1H-pyrazole-4carbonitrile (10c). Yield 36\%; m.p. 232-234 ${ }^{\circ} \mathrm{C}$; IR $\left(\mathrm{KBr}, \mathrm{cm}^{-1}\right): 2212(\mathrm{C} \equiv \mathrm{N}), 1785$ and $1713(2 \mathrm{C}=\mathrm{O}$, isoindoline-1,3-dione); ${ }^{1} \mathrm{H}-\mathrm{NMR}$ (DMSO-d6) $\delta 2.1$ (s, 3H, $\left.\mathrm{CH}_{3}\right), 2.63\left(\mathrm{~s}, 3 \mathrm{H}, \mathrm{CH}_{3}\right), 7.64(\mathrm{~d}, 3 \mathrm{H}, J=8 \mathrm{~Hz}$, Ar-H), 7.96-8.09 (m, 7H, Ar-H), 8.11 (d, 3H, $J=8 \mathrm{~Hz}, \mathrm{Ar}-\mathrm{H}) ;{ }^{13} \mathrm{C}-\mathrm{NMR}\left(\mathrm{DMSO}-d_{6}\right) \delta 11.60,18.40$, 92.51, 115.04, 123.80, 123.94, 124.04, 126.20, 127.54,129.25, 131.98, 132.20, 135.34, 136.30, 136.49, 150.20, 150.40, 158.40, 167.13; MS (m/z, \%): $445\left(\mathrm{M}^{+}, 1.47 \%\right), 70(100 \%)$; Anal. Calcd. for $\mathrm{C}_{27} \mathrm{H}_{19} \mathrm{~N}_{5} \mathrm{O}_{2}$ : C, 72.80; H, 4.30; N, 15.72. Found: C, 72.68; H, 4.42; N, 15.63\%.

\subsubsection{General Procedure for the Synthesis of Compounds 11a-c}

A mixture of 9 (2.65 g, $0.01 \mathrm{~mol})$ and the corresponding $o$-amino derivative $(0.01 \mathrm{~mol})$ was refluxed in absolute ethanol $(30 \mathrm{~mL})$ containing a catalytic amount of glacial acetic acid $(0.5 \mathrm{~mL})$ for $12 \mathrm{~h}$. The solid separated on hot was filtered, dried and crystallized from DMF.

2-[4-(2-Methyl-2,3-dihydro-1H-benzo[d] imidazol-2-yl)phenyl]isoindoline-1,3-dione (11a). Yield 46\%; m.p. 292-294 ${ }^{\circ} \mathrm{C}$; IR (KBr, cm ${ }^{-1}$ ): 3447 (broad band, 2NH), 1785 and 1714 (2C=O, isoindoline-1,3-dione); ${ }^{1} \mathrm{H}-\mathrm{NMR}\left(\mathrm{DMSO}, d_{6}\right) \delta 2.09$ (s, 3H, CH ), 3.35 (s, 1H, NH, D $\mathrm{O}_{2}$ exchangeable), 7.22-7.46 (m, 3H, Ar-H), 7.61-7.63 (m, 3H, Ar-H), 7.65 (s, 1H, NH, D $2 \mathrm{O}$ exchangeable), 7.71, 7.72 (dd, 2H, $J=3.2 \mathrm{~Hz}$, $3.2 \mathrm{~Hz}, \mathrm{Ar}-\mathrm{H}), 7.92,8.01$ (dd, $1 \mathrm{H}, J=3.2 \mathrm{~Hz}, 3.2 \mathrm{~Hz}, \mathrm{Ar}-\mathrm{H}), 8.09-8.24$ (m, 3H, Ar-H); ${ }^{13} \mathrm{C}-\mathrm{NMR}$ $\left(\mathrm{DMSO}-d_{6}\right) \delta 26.30,74.70,112.91,117.70,120.20,124.03,127.34,128.09,129.75,131.02,132.30$, 136.72, 169.08; MS (m/z, \%): $355\left(\mathrm{M}^{+}, 0.17 \%\right), 77(100 \%)$; Anal. Calcd. for $\mathrm{C}_{22} \mathrm{H}_{17} \mathrm{~N}_{3} \mathrm{O}_{2}$ : C, 74.35 ; $\mathrm{H}$, 4.82; N, 11.82. Found: C, 74.13; H, 4.62; N, 11.80\%. 
2-[4-(2-Methyl-2,3-dihydrobenzo[d]oxazol-2-yl)phenyl]isoindoline-1,3-dione (11b). Yield 26\%; m.p. 229-231 ${ }^{\circ} \mathrm{C}$; IR $\left(\mathrm{KBr}, \mathrm{cm}^{-1}\right): 3470(\mathrm{NH}), 1786$ and 1713 (2C=O, isoindoline-1,3-dione); ${ }^{1} \mathrm{H}-\mathrm{NMR}$ (DMSO-d6) $\delta 2.46\left(\mathrm{~s}, 3 \mathrm{H}, \mathrm{CH}_{3}\right), 4.38\left(\mathrm{~s}, 1 \mathrm{H}, \mathrm{NH}, \mathrm{D}_{2} \mathrm{O}\right.$ exchangeable), $7.64(\mathrm{~d}, 3 \mathrm{H}, J=8 \mathrm{~Hz}, \mathrm{Ar}-\mathrm{H})$, 7.99-8.00 (m, 6H, Ar-H), 8.11 (d, 3H, $J=8 \mathrm{~Hz}, \mathrm{Ar}-\mathrm{H}) ;{ }^{13} \mathrm{C}-\mathrm{NMR}$ (DMSO-d6) $\delta$ 27.32, 98.21, 113.05, 114.01, 124.03, 126.90, 127.54, 128.20, 129.24, 131.99, 132.50, 135.33, 136.29, 136.50, 142.60, 167.13; MS (m/z, \%): $356\left(\mathrm{M}^{+}, 0.36 \%\right), 309$ (100\%); Anal. Calcd. for $\mathrm{C}_{22} \mathrm{H}_{16} \mathrm{~N}_{2} \mathrm{O}_{3}$ : C, 74.15; H, 4.53; N, 7.86. Found: C, 74.31; H, 4.62; N, 7.80\%.

2-[4-(2-Methyl-2,3-dihydrobenzo[d]thiazol-2-yl)phenyl]isoindoline-1,3-dione (11c). Yield 29\%; m.p. $>300{ }^{\circ} \mathrm{C}$; IR $\left(\mathrm{KBr}, \mathrm{cm}^{-1}\right): 3456(\mathrm{NH}), 1781$ and $1714\left(2 \mathrm{C}=\mathrm{O}\right.$, isoindoline-1,3-dione); ${ }^{1} \mathrm{H}-\mathrm{NMR}$ (DMSO-d6) $\delta 2.50$ (s, 3H, CH3), 4.45 (s, 1H, NH, $\mathrm{D}_{2} \mathrm{O}$ exchangeable), 7.19 (t, 1H, J=7.2 Hz, Ar-H), 7.28 (t, 1H, J=7.2 Hz, Ar-H), 7.50-7.52 (m, 2H, Ar-H), 7.56-7.65 (m, 2H, Ar-H), 7.67-7.94 (m, 4H, Ar-H), 7.98 (d, 2H, $J=8.4 \mathrm{~Hz}, \mathrm{Ar}-\mathrm{H}) .{ }^{13} \mathrm{C}-\mathrm{NMR}$ (DMSO-d6) $\delta$ 27.32, 66.81, 122.48, 123.96, 124.03, 127.53, 127.71, 127.76, 129.24, 129.36, 131.98, 135.25, 135.33, 136.28, 136.49, 167.13; MS (m/z, \%): $372\left(\mathrm{M}^{+}, 8.50 \%\right), 370$ (100\%); Anal. Calcd. for $\mathrm{C}_{22} \mathrm{H}_{16} \mathrm{~N}_{2} \mathrm{O}_{2} \mathrm{~S}: \mathrm{C}, 70.95 ; \mathrm{H}, 4.33$; N, 7.52. Found: C, 70.73; H, 4.35; N, 7.31\%.

\subsubsection{Synthesis of (ZE)-2-[4-(1-Hydrazonoethyl)phenyl]isoindoline-1,3-dione (12)}

To a solution of compound $9(2.65 \mathrm{~g}, 0.01 \mathrm{~mol})$ in dioxane $(30 \mathrm{~mL})$, hydrazine hydrate $99.99 \%$ $(0.55 \mathrm{~g}, 0.011 \mathrm{~mol})$ was added and the reaction mixture was heated at reflux temperature for $2 \mathrm{~h}$. The solid separated while hot was filtered, dried and crystallized from DMF. Yield 24\%; m.p. $>300{ }^{\circ} \mathrm{C}$; IR $\left(\mathrm{KBr}, \mathrm{cm}^{-1}\right): 3317,3235\left(\mathrm{NH}_{2}\right), 1785$ and 1714 (2C=O, isoindoline-1,3-dione); ${ }^{1} \mathrm{H}-\mathrm{NMR}$ (DMSO- $\left.d_{6}\right)$ $\delta 2.23$ (s, 3H, $\left.\mathrm{CH}_{3}\right), 5.79$ (s, 2H, NH${ }_{2}, \mathrm{D}_{2} \mathrm{O}$ exchangeable), 7.81-7.99 (m, 4H, Ar-H), 8.07-8.14 (m, 4H, Ar-H); ${ }^{13} \mathrm{C}-\mathrm{NMR}$ (DMSO-d 6 ) $\delta 14.46,113.60,125.67,126.24,127.13,128.11,132.20,132.73,150.82$, 167.31; MS (m/z, \%): $279\left(\mathrm{M}^{+}, 11.71 \%\right), 370$ (100\%); Anal. Calcd. for $\mathrm{C}_{16} \mathrm{H}_{13} \mathrm{~N}_{3} \mathrm{O}_{2}: \mathrm{C}, 68.81 ; \mathrm{H}, 4.69$; N, 15.05. Found: C, 68.67; H, 4.55; N, 14.99\%.

\subsubsection{General procedure for the Synthesis of Compounds 13a-c}

A mixture of $12(2.79 \mathrm{~g}, 0.01 \mathrm{~mol})$ and the corresponding isocyanate and/or isothiocyanate derivative $(0.01 \mathrm{~mol})$ was refluxed in dioxane $(30 \mathrm{~mL})$ for $5 \mathrm{~h}$. The solid separated while hot was filtered, dried and crystallized from $\mathrm{DMF} / \mathrm{MeOH}$.

2-\{4-[4-(4-Chlorophenyl)-3-methyl-5-oxo-1,2,4-triazolidin-3-yl]phenyl\}isoindoline-1,3-dione (13a). Yield 47\%; m.p. 254-256 ${ }^{\circ} \mathrm{C}$; IR (KBr, cm $\left.{ }^{-1}\right)$ : 3299, $3224(2 \mathrm{NH}), 1785$ and $1714(2 \mathrm{C}=\mathrm{O}$, isoindoline-1,3dione), $1671(\mathrm{C}=\mathrm{O})$; ${ }^{1} \mathrm{H}-\mathrm{NMR}\left(\mathrm{DMSO}-d_{6}\right) \delta 2.50\left(\mathrm{~s}, 3 \mathrm{H}, \mathrm{CH}_{3}\right), 7.31(\mathrm{~d}, 4 \mathrm{H}, J=8.8 \mathrm{~Hz}, \mathrm{Ar}-\mathrm{H}), 7.34$ (d, 4H, $J=8.8 \mathrm{~Hz}, \mathrm{Ar}-\mathrm{H}), 7.54-7.67$ (m, 1H, Ar-H), 7.88-8.15 (m, 3H, Ar-H), 8.96 (s, 1H, NH, D $2 \mathrm{O}$ exchangeable), 11.54 (s, $1 \mathrm{H}, \mathrm{NH}, \mathrm{D}_{2} \mathrm{O}$ exchangeable); ${ }^{13} \mathrm{C}-\mathrm{NMR}$ (DMSO-d6) $\delta 27.70,87.03,118.17$, $120.31,120.55,123.70,125.86,127.75,128.90,129.12,130.70,132.20,139.20,156.39,167.31$; MS (m/z, \%): $432.5\left(\mathrm{M}^{+}, 0.7 \%\right), 104(100 \%)$; Anal. Calcd. for $\mathrm{C}_{23} \mathrm{H}_{17} \mathrm{ClN}_{4} \mathrm{O}_{3}: \mathrm{C}, 63.82 ; \mathrm{H}, 3.96 ; \mathrm{N}, 12.94$. Found: C, 64.02; H, 3.75; N, 13.11\%. 
2-[4-(4-Ethyl-3-methyl-5-thioxo-1,2,4-triazolidin-3-yl)phenyl]isoindoline-1,3-dione (13b). Yield 39\%; m.p. $247-249{ }^{\circ} \mathrm{C}$; IR (KBr, cm $\left.{ }^{-1}\right): 3259,3158(2 \mathrm{NH}), 1782$ and 1713 (2C=O, isoindoline-1,3-dione), $1216(\mathrm{C}=\mathrm{S}) ;{ }^{1} \mathrm{H}-\mathrm{NMR}\left(\mathrm{DMSO}-d_{6}\right) \delta 1.13\left(\mathrm{t}, 3 \mathrm{H}, J=6 \mathrm{~Hz}, \mathrm{CH}_{2} \mathrm{CH}_{3}\right), 2.50$ (s, 3H, CH$), 3.61$ (q, 2H, $\left.J=6 \mathrm{~Hz}, \mathrm{CH}_{2} \mathrm{CH}_{3}\right), 7.88-7.98(\mathrm{~m}, 5 \mathrm{H}, \mathrm{Ar}-\mathrm{H}), 8.06-8.23(\mathrm{~m}, 3 \mathrm{H}, \mathrm{Ar}-\mathrm{H}), 9.15\left(\mathrm{~s}, 1 \mathrm{H}, \mathrm{NH}, \mathrm{D}_{2} \mathrm{O}\right.$ exchangeable), 11.54 (s, 1H, NH, $\mathrm{D}_{2} \mathrm{O}$ exchangeable); ${ }^{13} \mathrm{C}-\mathrm{NMR}$ (DMSO- $d 6$ ) $\delta 15.03,37.13,40.59$, $90.03,123.70,125.59,127.38,128.63,132.20,133.06,147.70,167.31,182.18 ; \mathrm{MS}(\mathrm{m} / \mathrm{z}, \%): 366$ $\left(\mathrm{M}^{+}, 0.5 \%\right), 104$ (100\%); Anal. Calcd. for $\mathrm{C}_{19} \mathrm{H}_{18} \mathrm{~N}_{4} \mathrm{O}_{2} \mathrm{~S}$ : C, 62.28; H, 4.95; N, 15.29. Found: C, 62.41; H, 4.78; N, $15.33 \%$.

2-[4-(3-Methyl-5-thioxo-4-phenyl-1,2,4-triazolidin-3-yl)phenyl]isoindoline-1,3-dione (13c). Yield 42\%; m.p. $>300{ }^{\circ} \mathrm{C}$; IR $\left(\mathrm{KBr}, \mathrm{cm}^{-1}\right): 3437,3164(2 \mathrm{NH}), 1785$ and $1714(2 \mathrm{C}=\mathrm{O}$, isoindoline-1,3-dione), 1217 $(\mathrm{C}=\mathrm{S}) ;{ }^{1} \mathrm{H}-\mathrm{NMR}$ (DMSO-d6) $\delta 2.50\left(\mathrm{~s}, 3 \mathrm{H}, \mathrm{CH}_{3}\right), 7.15$ (t, $\left.1 \mathrm{H}, J=7.2 \mathrm{~Hz}, \mathrm{Ar}-\mathrm{H}\right), 7.33$ (t, 2H, $J=7.6 \mathrm{~Hz}$, Ar-H), 7,54 (d, 2H, $J=7.2 \mathrm{~Hz}, \mathrm{Ar}-\mathrm{H}), 7.88-7.99$ (m, 4H, Ar-H), 8.06-8.19 (m, 4H, Ar-H), 9.45 (s, $1 \mathrm{H}, \mathrm{NH}, \mathrm{D}_{2} \mathrm{O}$ exchangeable), $11.54\left(\mathrm{~s}, 1 \mathrm{H}, \mathrm{NH}, \mathrm{D}_{2} \mathrm{O}\right.$ exchangeable); ${ }^{13} \mathrm{C}-\mathrm{NMR}$ (DMSO-d6) $\delta 14.44$, 70.80, 123.92, 125.60, 127.36, 127.50, 132.02, 133.02, 133.5, 135.23, 137.63, 139.81, 147.49, 167.39, 179.39; MS (m/z, \%): $414\left(\mathrm{M}^{+}, 1.25 \%\right), 104(100 \%)$; Anal. Calcd. for $\mathrm{C}_{23} \mathrm{H}_{18} \mathrm{~N}_{4} \mathrm{O}_{2} \mathrm{~S}: \mathrm{C}, 66.65 ; \mathrm{H}, 4.38$; N, 13.52. Found: C, 66.42; H, 4.17; N, 13.55\%.

\subsubsection{Synthesis of 2-[4-(3-Methyl-5-thioxo-1,2,4-triazolidin-3-yl)-phenyl]isoindole-1,3-dione (14)}

To a solution of $9(2.65 \mathrm{~g}, 0.01 \mathrm{~mol})$ in dioxane $(30 \mathrm{~mL})$, thiosemicarbazide $(0.91 \mathrm{~g}, 0.01 \mathrm{~mol})$ was added. The reaction mixture was refluxed for $3 \mathrm{~h}$. The solid separated on hot was filtered, dried and crystallized from DMF/acetone. Yield 33\%; m.p. $>300{ }^{\circ} \mathrm{C}$; IR $\left(\mathrm{KBr}, \mathrm{cm}^{-1}\right): 3417-3271(3 \mathrm{NH}), 1781$ and $1707\left(2 \mathrm{C}=\mathrm{O}\right.$, isoindoline-1,3-dione), $1222(\mathrm{C}=\mathrm{S})$; ${ }^{1} \mathrm{H}-\mathrm{NMR}$ (DMSO-d6) $\delta 2.35\left(\mathrm{~s}, 3 \mathrm{H}, \mathrm{CH}_{3}\right), 7.48$ (d, 2H, $J=8.4 \mathrm{~Hz}, \mathrm{Ar}-\mathrm{H}), 7.90,7.91(\mathrm{dd}, 2 \mathrm{H}, J=3.6 \mathrm{~Hz}, 2.8 \mathrm{~Hz}, \mathrm{Ar}-\mathrm{H}), 7.94,7.96$ (dd, 2H, $J=8 \mathrm{~Hz}$, $2.8 \mathrm{~Hz}, \mathrm{Ar}-\mathrm{H}), 8.04$ (s, 1H, NH, $\mathrm{D}_{2} \mathrm{O}$ exchangeable), 8.09 (d, 2H, $\left.J=8 \mathrm{~Hz}, \mathrm{Ar}-\mathrm{H}\right), 8.35$ (s, 1H, NH, $\mathrm{D}_{2} \mathrm{O}$ exchangeable), $10.31\left(\mathrm{~s}, 1 \mathrm{H}, \mathrm{NH}, \mathrm{D}_{2} \mathrm{O}\right.$ exchangeable); ${ }^{13} \mathrm{C}-\mathrm{NMR}$ (DMSO- $\left.d_{6}\right) \delta 14.44,66.80$, 123.92, 127.36, 127.50, 132.02, 133.02, 135.23, 137.63, 167.39, 179.40; $\mathrm{MS}(\mathrm{m} / \mathrm{z}, \%): 338\left(\mathrm{M}^{+}, 0.22 \%\right)$, 153 (100\%); Anal. Calcd. for $\mathrm{C}_{17} \mathrm{H}_{14} \mathrm{~N}_{4} \mathrm{O}_{2} \mathrm{~S}$ : C, 60.34; H, 4.17; N, 16.65. Found: C, 60.52; H, 4.17; $\mathrm{N}, 16.84 \%$.

\subsubsection{Synthesis of (ZE)- $N^{\prime}-\{1-[4-(1,3-D i o x o i n d o l i n-2-y 1)$ phenyl] ethylidene $\}$ benzohydrazide (15)}

A mixture of 9 (2.65 g, $0.01 \mathrm{~mol})$ and benzohydrazide $(1.36 \mathrm{~g}, 0.01 \mathrm{~mol})$ was refluxed in dioxane $(30 \mathrm{~mL})$ for $7 \mathrm{~h}$. The solid separated on hot was filtered, dried and crystallized from propanol. Yield 48\%; m.p. 247-249 ${ }^{\circ} \mathrm{C}$; IR ( $\left.\mathrm{KBr}, \mathrm{cm}^{-1}\right)$ : $3330(\mathrm{NH}), 1781$ and 1704 (2C=O, isoindoline-1,3-dione), $1672(\mathrm{C}=\mathrm{O})$; ${ }^{1} \mathrm{H}-\mathrm{NMR}$ (DMSO-d6) $\delta$ 2.56, 2.64 (2s, 3H, syn \& anti $\left.\mathrm{CH}_{3}\right), 7.59-7.68$ (m, 5H, Ar-H), 7.98-8.10 (m, 8H, Ar-H), 10.85 (s, $1 \mathrm{H}, \mathrm{NH}, \mathrm{D}_{2} \mathrm{O}$ exchangeable); ${ }^{13} \mathrm{C}-\mathrm{NMR}$ (DMSO-d6) $\delta 22.70,123.95$, 124.50, 127.30, 127.51, 128.41, 128.79, 129.40, 132.03, 133.11 135.25, 138.09, 147.79, 163.20, 167.36; MS (m/z, \%): $383\left(\mathrm{M}^{+}, 4.05 \%\right), 105$ (100\%); Anal. Calcd. for $\mathrm{C}_{23} \mathrm{H}_{17} \mathrm{~N}_{3} \mathrm{O}_{3}: \mathrm{C}, 70.05 ; \mathrm{H}, 4.47 ; \mathrm{N}, 10.96$. Found: C, 69.98; H, 4.25; N, 10.97\%. 


\subsubsection{Synthesis of 2-[4-(2-Methyl-2H-imidazol-2-yl)phenyl]isoindole-1,3-dione (16)}

To a solution of $9(2.65 \mathrm{~g}, 0.01 \mathrm{~mol})$ in dioxane $(30 \mathrm{~mL})$, ethylenediamine $(0.6 \mathrm{~g}, 0.01 \mathrm{~mol})$ was added. The reaction mixture was refluxed for $4 \mathrm{~h}$. The solution was allowed to cool; the solid separated was filtered, dried and crystallized from ethanol 95\%. Yield (26\%); m.p. 215-217 ${ }^{\circ} \mathrm{C}$; IR $\left(\mathrm{KBr}, \mathrm{cm}^{-1}\right)$ : 1781 and $1704\left(2 \mathrm{C}=\mathrm{O}\right.$, isoindoline-1,3-dione); ${ }^{1} \mathrm{H}-\mathrm{NMR}\left(\mathrm{DMSO}-\mathrm{d}_{6}\right) \delta 2.62\left(\mathrm{~s}, 3 \mathrm{H}, \mathrm{CH}_{3}\right), 6.56(\mathrm{~d}, 1 \mathrm{H}$, $J=8.4 \mathrm{~Hz}, \mathrm{Ar}-\mathrm{H}), 7.49-7.54(\mathrm{~m}, 8 \mathrm{H}, \mathrm{Ar}-\mathrm{H}), 7.66(\mathrm{~d}, 1 \mathrm{H}, J=8.4 \mathrm{~Hz}, \mathrm{Ar}-\mathrm{H}) ;{ }^{13} \mathrm{C}-\mathrm{NMR}$ (DMSO- $\left.d_{6}\right)$ $\delta 27.32,66.81,124.03,127.53,128.58,129.24,131.98,135.33,136.28,136.49,167.13$; MS (m/z, \%): $303\left(\mathrm{M}^{+}, 5.6 \%\right), 80(100 \%)$; Anal. Calcd. for $\mathrm{C}_{18} \mathrm{H}_{13} \mathrm{~N}_{3} \mathrm{O}_{2}: \mathrm{C}, 71.28 ; \mathrm{H}, 4.32 ; \mathrm{N}, 13.85$. Found: C, $71.08 ; \mathrm{H}, 4.27 ; \mathrm{N}, 14.01 \%$.

\subsubsection{General Procedure for the Synthesis of Compounds $\mathbf{1 7 a - c}$}

A mixture of 9 (2.65 g, $0.01 \mathrm{~mol})$ and the corresponding phenyl hydrazine hydrochloride derivative $(0.01 \mathrm{~mol})$ was heated at reflux temperature in absolute ethanol $(30 \mathrm{~mL})$ for $5-8 \mathrm{~h}$ (monitored by TLC). The solid separated on hot was filtered, dried and crystallized from dioxane.

2-\{4-[1-(Phenyl-hydrazono)-ethyl]-phenyl\}-isoindole-1,3-dione (17a). Yield 49\%; m.p. 185-187 ${ }^{\circ} \mathrm{C}$; IR $\left(\mathrm{KBr}, \mathrm{cm}^{-1}\right): 3355(\mathrm{NH}), 1783$ and $1711\left(2 \mathrm{C}=\mathrm{O}\right.$, isoindoline-1,3-dione); ${ }^{1} \mathrm{H}-\mathrm{NMR}$ (DMSO- $\left.d_{6}\right)$ $\delta$ 2.30, 2.63 (2s, 3H, syn \& anti $\left.\mathrm{CH}_{3}\right), 7.26-7.45$ (m, 3H, Ar-H), 7.47 (d, 1H, J=8.4 Hz, Ar-H), 7.64 (d, $1 \mathrm{H}, J=8.8 \mathrm{~Hz}, \mathrm{Ar}-\mathrm{H}), 7.93-7.97$ (m, 4H, Ar-H), 7.99 (m, 3H, Ar-H), 8.11 (d, 1H, J=8.8 Hz, Ar-H), 9.87 (s, 1H, NH, $\mathrm{D}_{2} \mathrm{O}$ exchangeable); ${ }^{13} \mathrm{C}-\mathrm{NMR}$ (DMSO-d $) \delta 13.27,113.34,119.49,124.03,127.53$, 128.58, 129.24, 131.98, 132.01, 135.33, 136.28, 139.35, 150.80, 167.49; MS (m/z, \%): $355\left(\mathrm{M}^{+}, 9.26 \%\right)$, 250 (100\%); Anal. Calcd. for $\mathrm{C}_{22} \mathrm{H}_{17} \mathrm{~N}_{3} \mathrm{O}_{2}$ : C, 74.35; H, 4.82; N, 11.82. Found: C, 74.28; H, 4.69; $\mathrm{N}, 12.03 \%$.

2-(4-\{1-[(4-Methanesulfonyl-phenyl)-hydrazono]-ethyl\}-phenyl)-isoindole-1,3-dione (17b). Yield 51\%; m.p. $208-210{ }^{\circ} \mathrm{C}$; IR $\left(\mathrm{KBr}, \mathrm{cm}^{-1}\right): 3330(\mathrm{NH}), 1783$ and $1714\left(2 \mathrm{C}=\mathrm{O}\right.$, isoindolne-1,3-dione); ${ }^{1} \mathrm{H}-\mathrm{NMR}$ $\left(\mathrm{DMSO}-d_{6}\right) \delta 2.36,2.63\left(2 \mathrm{~s}, 3 \mathrm{H}\right.$, syn \& anti $\left.\mathrm{CH}_{3}\right), 3.12\left(\mathrm{~s}, 3 \mathrm{H}, \mathrm{SO}_{2} \mathrm{CH}_{3}\right), 7.42(\mathrm{~d}, 1 \mathrm{H}, J=8.8 \mathrm{~Hz}$, Ar-H), 7.50 (d, 1H, J=8.2 Hz, Ar-H), 7.64 (d, 2H, $J=8.8 \mathrm{~Hz}, \mathrm{Ar}-\mathrm{H}), 7.75$ (d, 1H, $J=8.2 \mathrm{~Hz}, \operatorname{Ar}-\mathrm{H})$, 7.96-8.01 (m, 5H, Ar-H), $8.11(\mathrm{~d}, 2 \mathrm{H}, J=8.4 \mathrm{~Hz}, \mathrm{Ar}-\mathrm{H}), 9.98$ (s, 1H, NH, D $2 \mathrm{O}$ exchangeable); ${ }^{13} \mathrm{C}-\mathrm{NMR}$ (DMSO- $\left.d_{6}\right) \delta 13.77,44.73,112.88,123.92,126.42,127.52,127.56,129.15,130.20,132.01$, 132.10, 135.22, 136.26, 150.26, 167.44; $\mathrm{MS}(\mathrm{m} / \mathrm{z}, \%): 433\left(\mathrm{M}^{+}, 58.21 \%\right), 163$ (100\%); Anal. Calcd. for $\mathrm{C}_{23} \mathrm{H}_{19} \mathrm{~N}_{3} \mathrm{O}_{4} \mathrm{~S}$ : C, 63.73; H, 4.42; N, 9.69. Found: C, 63.58; H, 4.66; N, 9.73\%.

4-(N'-\{1-[4-(1,3-Dioxo-1,3-dihydro-isoindol-2-yl)-phenyl]-ethylidene\}-hydrazino)-benzenesulfonamide (17c). Yield 52\%; m.p. 265-267 ${ }^{\circ} \mathrm{C}$; IR $\left(\mathrm{KBr}, \mathrm{cm}^{-1}\right)$ : 3428-3258 $\left(\mathrm{NH}_{2}\right.$ and $\left.\mathrm{NH}\right), 1784$ and 1711 (2C=O, isoindoline-1,3-dione); ${ }^{1} \mathrm{H}-\mathrm{NMR}\left(\mathrm{DMSO}-d_{6}\right) \delta 2.34,2.51\left(2 \mathrm{~s}, 3 \mathrm{H}\right.$, syn \& anti $\left.\mathrm{CH}_{3}\right), 7.1(\mathrm{~s}, 2 \mathrm{H}$, $\mathrm{NH}_{2}, \mathrm{D}_{2} \mathrm{O}$ exchangeable), $7.36(\mathrm{~d}, 2 \mathrm{H}, J=8.8 \mathrm{~Hz}, \mathrm{Ar}-\mathrm{H}), 7.49(\mathrm{~d}, 2 \mathrm{H}, J=8.8 \mathrm{~Hz}, \mathrm{Ar}-\mathrm{H}), 7.68(\mathrm{~d}, 2 \mathrm{H}$, $J=8.8 \mathrm{~Hz}, \mathrm{Ar}-\mathrm{H}), 7.96-8.12$ (m, 6H, Ar-H), 9.88 (s, 1H, NH, $\mathrm{D}_{2} \mathrm{O}$ exchangeable); ${ }^{13} \mathrm{C}-\mathrm{NMR}$ (DMSO- $d_{6}$ ) $\delta$ 13.65, 112.56, 123.92, 126.32, 127.57, 127.71, 131.93, 132.03, 134.21, 135.22, 138.89, 142.89, 148.90, 167.47; MS (m/z, \%): $434\left(\mathrm{M}^{+}, 32.06 \%\right), 88(100 \%)$; Anal. Calcd. for $\mathrm{C}_{22} \mathrm{H}_{18} \mathrm{~N}_{4} \mathrm{O} 4 \mathrm{~S}: \mathrm{C}, 60.82$; H, 4.18; N, 12.90. Found: C, 60.69; H, 4.17; N, 12.73\%. 


\subsection{Biological Testing}

\subsubsection{Antimicrobial Sensitivity Test Using Agar Diffusion Method (Cup Technique)}

The cup plate method is an accepted method when test samples diffuse from the cup through an agar layer in a Petri dish or plate to such an extent that the growth of added microorganisms is completely restricted to a circular area or zone around the cavity containing the solution of an antibiotic substance [23]. The anti-microbial activity was expressed as zone diameter in millimetres, which is measured by a ruler [24].

\section{Microorganisms}

Gram-positive organisms used in the study were Staphylococcus aureus LMG 3242, Sarcina lutea, Enterococcus faecalis OS4, Listeria innocua LMG 2710, Mycobacterium pheli and Bacillus subtilis. Gram-negative organisms used were Escherichia coli ATCC 5087, Escherichia coli ATCC 25922, Proteus vulgaris and Pseudomonas aeruginosa. The yeast used was Candida albicans.

Standard Antimicrobials

Gentamicin (CN), Cefotaxime (CTX), Ampicillin (AMP), Fluconazole (FLU) and Tioconazole (TIO) were all were prepared in concentration of $10 \mathrm{mg} / \mathrm{mL}$.

Preparation of Sample Stock Solutions

All test samples $(\mathbf{1 0 a}-\mathbf{c}, \mathbf{1 1 a}-\mathbf{c}, \mathbf{1 2}, \mathbf{1 3 a}-\mathbf{c}, \mathbf{1 4}, \mathbf{1 5}, \mathbf{1 6}, \mathbf{1 7} \mathbf{a}-\mathbf{c})$ were dissolved in DMSO to give a final concentration of $10 \mathrm{mg} / \mathrm{mL}$.

\section{Experimental Procedure}

Each overnight culture of the tested microorganisms was mixed with Muller Hinton agar media to give a final concentration of $1 \%$ microorganism (about $0.5 \mathrm{McF}$ arland) and poured into sterile Petri dishes in a fixed amount of $20 \mathrm{~mL}$ under aseptic conditions. A sterile cork borer was used to prepare cups of $10 \mathrm{~mm}$ diameter. Test samples and standard drugs with volumes of $60 \mu \mathrm{L}$ were introduced into the cups using a micropipette. All the plates were kept at room temperature for effective diffusion of the test drug and standard and incubated at $37 \pm 1{ }^{\circ} \mathrm{C}$ for $24 \mathrm{~h}$. The presence of inhibition zones around the cup indicated antibacterial activity. The diameter of the zone of inhibition was measured and recorded [25]. The percentage inhibition activities of tested compounds relative to standard antibiotics were calculated by applying this equation:

The percentage inhibition $=($ Zone of inhibition of tested compound - cup diameter $) /$ (Zone of inhibition of standard antibiotic - cup diameter) $\times 100$ 
Determination of Minimum Inhibitory Concentration (MIC) Using Agar Dilution Method According to Clinical Laboratory Standards Institute (CLSI)

For each sample, different concentrations were diluted with Muller Hinton agar to give a final concentration ranging from $(200 \mu \mathrm{g} / \mathrm{mL}-0.7 \mu \mathrm{g} / \mathrm{mL})$. DMSO was used as negative control plate. All bacterial isolates were subcultured on Brain Heart Infusion agar (B.H.I.A.) and incubated at $37^{\circ} \mathrm{C}$ for $24 \mathrm{~h}[26,27]$. Three colonies of each microorganism were suspended in $5 \mathrm{~mL}$ saline, and the suspension was adjusted to $0.5 \mathrm{McFarland}$ standards and then diluted 10-fold with saline to give an organism suspension of $\left(1 \times 10^{6}\right.$ to $\left.5 \times 10^{6} \mathrm{CFU} / \mathrm{mL}\right)$. This suspension was then further diluted by putting $1 \mathrm{~mL}$ suspension in $9 \mathrm{~mL}$ saline to give a final suspension volume of $1 \times 10^{5}$ to $5 \times 10^{5} \mathrm{CFU} / \mathrm{mL}$. A multiple inoculator was used to inoculate the prepared agar plates. A $100 \mu \mathrm{L}$ (i.e., $10^{4} \mathrm{CFU}$ ) of the prepared inoculums were put in the well of a multi-inoculator, where each inoculation time by multi-inoculator gave about $10 \mu \mathrm{L}$ of prepared inoculums per plate (i.e., $10^{3} \mathrm{CFU}$ ). Each experiment was performed in duplicate. All plates were incubated at $35{ }^{\circ} \mathrm{C}$ for $48 \mathrm{~h}$. The results were recorded in terms of MIC, which is the lowest concentration of antimicrobial/antifungal agent causing almost complete inhibition of growth or giving no visible growth.

\subsubsection{Anti-Oxidant Testing}

\section{Determination of Oxygen Radical Absorbance Capacity (ORAC)}

Oxygen radical absorbance capacity (ORAC) was determined as described previously [28]. Briefly, $100 \mu \mathrm{L}$ of $500 \mathrm{nM}$ fluorescein and $25 \mu \mathrm{L}$ of diluted solutions of tested compounds were pipetted into each working well of a microplate (96 well) preincubated at $37{ }^{\circ} \mathrm{C} .25 \mu \mathrm{L}$ of $250 \mathrm{mM}$ AAPH was then added and the microplate was shaken for $5 \mathrm{~s}$ in a fluorometer Infinite 200 (Tecan, Mannedorf, Switzerland). The fluorescence (Ex. $485 \mathrm{~nm}, \mathrm{Em} .510 \mathrm{~nm}$ ) was read every $2 \mathrm{~min}$ for $60 \mathrm{~min}$. The net area under the curve was used to calculate ORAC which was expressed as a ratio between tested compound and trolox on an equimolar basis.

\subsubsection{Anti-Inflammatory Testing}

\section{Cell Culture}

Stock solutions $(10 \mathrm{mmol} / \mathrm{L})$ of tested compounds were prepared by dissolving an appropriate quantity of each substance in DMSO. Dulbecco's modified Eagle's medium (DMEM, RPMI 1640 medium), foetal bovine serum (FBS), L-glutamine, penicillin and streptomycin were purchased from Sigma (St. Louis, MO, USA). Calcein AM was obtained from Molecular Probes (Life Technologies, Carlsbad, CA, USA).

The screening cell lines (T-lymphoblastic leukaemia cell line CEM, breast carcinoma cell line MCF7, cervical carcinoma cell line HeLa and human fibroblasts BJ) were obtained from the American Type Culture Collection (Manassas, VA, USA). CEM cell line were cultured in RPMI 1640 medium and the others in DMEM medium (Sigma); both media supplemented with $10 \%$ foetal bovine serum, $2 \mathrm{mmol} / \mathrm{L}$ L-glutamine, 10,000 $\mathrm{U}$ penicillin and $10 \mathrm{mg} / \mathrm{mL}$ streptomycin. The cell lines were maintained 
under standard cell culture conditions at $37{ }^{\circ} \mathrm{C}$ and $5 \% \mathrm{CO}_{2}$ in a humid environment. Cells were subcultured twice or three times a week using the standard trypsinization procedure.

Human Umbilical Vein Endothelial Cells (HUVEC) were cultured in ECGM medium (Endothelial Cell Growth Medium, Provitro, Berlin, Germany), supplemented with 10\% foetal bovine serum (Sigma-Aldrich, Munich, Germany). Cells were maintained under standard cell culture conditions at $37{ }^{\circ} \mathrm{C}$ and $5 \% \mathrm{CO}_{2}$ in a humid environment. Cells were subcultured twice or three times a week using the standard trypsinization procedure. HUVECs were a kind gift from Prof Jitka Ulrichová (Medical Faculty, Palacky University, Olomouc, The Czech Republic).

\section{CD62E (E-Selectin, ELAM)-induction Assays}

Each well of the 96-well plates were coated with collagen $\mathrm{G}$ by applying $200 \mu \mathrm{L}$ for 15 min at $37{ }^{\circ} \mathrm{C}$. Outer wells (A1-A12, H1-H12, 1-H1 and A12-H12) contained only $200 \mu \mathrm{L} /$ well medium and served as an evaporation barrier. $1 \times 10^{4}$ HUVECs (Human Umbilical Vein Endothelial Cells) were seeded in each of the other wells in $200 \mu \mathrm{L}$ medium and grown for $48 \mathrm{~h}$ to optimal confluence. Increasing concentrations of compounds were then added to the HUVEC-containing wells in triplicates, and the cells were incubated for $30 \mathrm{~min}$, after which $10 \mathrm{ng} / \mathrm{mL}$ TNF $\alpha$ was added per well to stimulate NF- $\mathrm{BB}$, and thus ELAM. After another $4 \mathrm{~h}$ incubation, the levels of ELAM in each of the HUVEC-containing wells were determined by enzyme-linked activity assays (ELISAs) as described below.

\section{Cell-Surface ELISA ELAM}

Cells were washed once with PBS and fixed with 0.1\% glutaraldehyde (Sigma-Aldrich), for 15 min at room temperature. The cells were then washed 3 times with $200 \mu \mathrm{L}$ per well PBS $/ 0.05 \%$ Tween 20 , blocked with $200 \mu \mathrm{L} /$ well $5 \%$ BSA/PBS for $1 \mathrm{~h}$, and washed again 3 times with $200 \mu \mathrm{L}$ per well PBS/0.05\% Tween 20. Anti-ELAM-antibody (clone BBA-1, R \& D Systems, Minneapolis, MN, USA) diluted $1: 5000$ in $0.1 \%$ BSA/PBS $(100 \mu \mathrm{L}$ per well) was then added for $1 \mathrm{~h}$ at room temperature and washed 5 times with $200 \mu \mathrm{L}$ per well PBS/0.05\% Tween 20 . Subsequently, goat anti mouse-HRP antibody (Sigma-Aldrich) diluted 1:10000 in $0.1 \% \mathrm{BSA} / \mathrm{PBS}(100 \mu \mathrm{L}$ per well) was applied and the cells were incubated for $1 \mathrm{~h}$ in the dark at room temperature and, after decanting, washed 5 times with $200 \mu \mathrm{L}$ per well PBS/0.05\% Tween 20. The HRP-activity of the cells in each of the wells was estimated using Fast-OPD (o-phenylenediamine dihydrochloride) (Sigma-Aldrich) assay as described [29] and absorbance was measured at $\mathrm{OD}_{492 \mathrm{~nm}}$ in a plate reader (Tecan).

\subsubsection{Cytotoxicity Testing}

For the ELAM expression assay the toxicity of tested compounds was assessed in HUVECs by Calcein AM (Molecular Probes, Invitrogen, Karlsruhe, Germany) cytotoxicity assays in 96-well microtiter plates [30]. $20 \mu \mathrm{L}$ portions of each of the compound concentrations were added in triplicate to the cells, which were then incubated at $37{ }^{\circ} \mathrm{C}$ in an atmosphere containing $5 \% \mathrm{CO}_{2}$ for $4 \mathrm{~h}$, after which Calcein AM solution was added for $1 \mathrm{~h}$ according to the manufacturer's instructions. The fluorescence of viable cells was quantified using a Fluoroskan Ascent instrument (Lab-systems, Vantaa, Finland) reader and on the basis of triplicate experiments the cytotoxic concentrations were calculated. Cytotoxicity of tested 
compounds was determined also in HUVEC after $24 \mathrm{~h}$ and in CEM, MCF7, HeLa and BJ after $72 \mathrm{~h}$ by Calcein AM assays as described above.

Molecular Modeling and Docking

The celecoxib-COX-2 crystal structure was obtained from (PDB: ID 3LN1) [21]. Docking of the ligand was carried out. The root mean square deviation was $0.50 \AA$. Docking was performed using London dGforce. Force field energy was used to refine the results. The most active compound $17 \mathbf{c}$ was docked by MOE after preparation of the selected compound through its $3 \mathrm{D}$ protonation and selecting the least energetic conformer. The same docking method used for both ligand and 17c. Amino acid interactions and hydrogen bond lengths were measured and summarized in (Table 4).

\section{Conclusions}

The tested compounds in this study were evaluated against Gram positive, Gram negative and Fungi. The most active phthalimide derivative as an anti-microbial agent was hydrazonoethyl-phenylisoindoline1,3-dione 12. Most phthalimide derivatives showed antimicrobial activity with the exception of 10a and 10b and 13a and 10 b on Gram negative bacteria, in addition to 13a which had no action on Candida albicans. None of the tested phthalimide derivatives had any cytotoxic activity. Two, 13b and 13c (ethyl and phenyl isothiocyanate derivatives) had anti-oxidant activity. Phthalimide derivatives had mild anti-inflammatory activity in vitro albeit a strong inhibition of E-selectin by $\mathbf{1 7 c}$.

\section{Acknowledgments}

Phoebe F. Lamie would like to express her deepest thanks to all the members of the NMR center at Beni Suef University, Beni Suef, Egypt for their efforts in analyzing all the prepared compounds. All cytotoxic, anti-inflammatory and anti-oxidant assays were financed by a Czech Ministry of Education grant from the National Program for Sustainability I (LO1204). We thank Jitka Ulrichová for the kind gift of HUVEC cells and Olga Hustáková for excellent technical assistance.

\section{Author Contributions}

P.F.L. proposed the subject and carry out the synthesis, purification and characterization of the compounds. J.N.P. conceived the study and participated in its design, results, discussion, and coordination. A.O.E.-G. carried out the anti-microbial screening. L.R. and J.G. carried out the anti-inflammatory, anti-oxidants and cytotoxic assay.

\section{Conflicts of Interest}

The authors have no conflict of interest to declare.

\section{References}

1. Kamal, A.; Bolla, N.R.; Srikanth, P.S.; Srivastava, A.K. Naphthalimide derivatives with therapeutic characteristics: A patent review. Expert Opin. Ther. Pat. 2013, 23, 299-317. 
2. Amin, K.M.; El-masry, A.H.; Mohamed, N.A.; Awad, G.E.A.; Habib, B.S. Synthesis, characterization and anti-microbial activity of some novel isoindole-1,3-dione derivatives. Der Pharm. Chem. 2013, 5, 97-108.

3. El-Gaby, M.S.A.; Zahran, M.A.; Ismail, M.M.F.; Ammar, Y.A.A. A novel Synthesis of dibenzo[c,f]chromenes, dibenzo[c,h]chromenes and benzo[7,8]chromeno[3,4-f]isoindoles as anti-microbial agents. IlFarmaco 2000, 55, 227-232.

4. Rajasekaran, S.; Rao, G.K.; Pai, S.; Ranjan, A. Design, synthesis, anti-bacterial and in vitro anti-oxidant activity of substituted 2H-benzopyran-2-one derivatives. Int. J. ChemTech Res. 2011, 3, 555-559.

5. Pophale, R.A.; Deodhar, M.N. Synthesis and evaluation of novel phthalimide derivatives as analgesic and anti-inflammatory agents. Der Pharm. Chem. 2010, 2, 185-193.

6. Bhatnagar, A.; Sharma, P.K.; Kumar, N.; Upadhyay, A. Synthesis and in vitro evaluation of anti-oxidant and anti-inflammatory activity of 3-[4,5-dihydro-(5-substituted phenyl)-1 H-pyrazol-3yl]-2H-chromen2-one derivatives. Pharm. Chem. J. 2012, 46, 482-487.

7. Bansode, T.N.; Shelke, J.V.; Dongre, V.G. Synthesis and antimicrobial activity of some new $N$-acyl substitutedphenothiazines. Eur. J. Med. Chem. 2009, 44, 5094-5098.

8. Siddiqui, N.J.; Idrees, M.; Khati, N.T.; Dhond, M.G. Synthesis and anti-microbial activities of some new pyrazoles, oxadiazoles and isoxazole bearing benzofuran moiety. S. Afr. J. Chem. 2013, 66, 248-253.

9. Anthony, P.; Bashir, N.; Parveen, R. Regioselectivesynthesisof 1,4-disubstituted 1,2,3-bistriazoles and their anti-fungal and anti-oxidant evaluation. Asian J. Biomed. Pharm. Sci. 2014, 4, 9-13.

10. Bosquesi, P.L.; Melo, T.R.F.; Vizioli, E.O.; Santos, J.L.; Chung, M.C. Anti-inflammatory drug design using a molecular hybridization approach. Pharmaceuticals 2011, 4, 1450-1474.

11. Kaur, J.; Bhardwaj, A.; Huang, Z.; Knaus, E.E. $N-1$ and $C-3$ substituted indole Schiff bases as selective COX-2 inhibitors: synthesis and biological evaluation. Bioorg. Med. Chem. 2012, 22, 2154-2159.

12. Kaplancikli, Z.A.; Altintop, M.D.; Ozdemir, A.; Turan, Z.G.; Khan, S.I.; Tabanca, N. Synthesis and biological evaluation of some hydrazine derivatives as anti-inflammatory agents. Lett. Drug Des. Discov. 2012, 9, 310-315.

13. Kushwaha, T.A. Synthesis of novel 2-benzylbenzo $[d]$ thzole-6-sulfonamide derivatives as potential anti-inflammatory agent. J. Chem. Pharm. Sci. 2014, 7, 34-38.

14. Shiradkar, M.R.; Ghodake, M.; Bothara, K.G.; Bhandari, S.V.; Nikalje, A.; Akula, K.C.; Desai, N.C.; Burange, P.J. Synthesis and anti-convulsant activity of clubbed thiazolidinone-barbituric acid and thiazolidinone-triazole derivatives. ARKIVOC 2007, XIV, 58-74.

15. Moffet, R.S. Central Nervous System Depressants. VII.1 pyridylcoumarins. J. Med. Chem. 1964, 7, 446-449.

16. Mavrova, A.T.; Wesselinova, D.; Tsenov, Y.A.; Denkova, P. Synthesis, cytotoxicity and effects of some 1,2,4-triazole and 1,3,4-thiadiazole derivatives on immunocompetent cells. Eur. J. Med. Chem. 2009, 44, 63-69.

17. Pertino, M.W.; Verdugo, V.; Theoduloz, C.; Hirschmann, G.S. Synthesis and anti-proliferative activity of some novel triazole derivatives from dehydroabietic acid. Molecules 2014, 19, 2523-2535.

18. Sharma, V.; Shrivastava, B.; Bhatia, R.; Bachwani, M.; Bachwani, M.; Khandelwal, R.; Ameta, J. Exploring potential of 1,2,4-triazole: A brief review. Pharmacol. Online 2011, 1, 1192-1222. 
19. Lamie, P.F. Synthesis and anti-microbial activity of some novel isoindoline-1,3-dione derivatives. J. Adv. Chem. 2014, 8, 1660-1666.

20. Abdellatif, K.R.; Chowdhury, M.A.; Dong, Y.; Velázquez, C.; Das, D.; Suresh, M.R.; Knaus, E.E. Diazen-1-ium-1,2-diolated nitric oxide donor ester prodrugs of 5-(4-hydroxymethylphenyl)-1-(4aminosulfonylphenyl)-3-trifluromethyl- $1 H$-pyrazole and its methanesulfonyl analog: Synthesis, biological evaluation and nitric oxide release studies. Bioorg. Med. Chem. 2008, 16, 9694-9698.

21. RCSB Protein Data Bank. Available online: http://www.rcsb.org/pdb/home/home.do (accessed on 24 August 2015).

22. Abdellatif, K.R.; Huang, Z.; Chowdhury, M.A.; Kaufman, S.; Knaus, E.E. A diazen-1-ium-1,2diolated nitric oxide donor ester prodrug of 3-(4-hydroxymethylphenyl)-4-(4-methanesulfonylphenyl)$5 H$-furan-2-one: Synthesis, biological evaluation and nitric oxide release studies. Bioorg. Med. Chem. Lett. 2011, 21, 3951-3956.

23. Seeley, H.W.; Van, D.P.J. A Laboratory Manual of Microbiology, 2nd ed.; Sons and Co: Bombay, India, 1975; pp. 55-80.

24. Ahmed, S.H.; Amin, M.A.; Saafan, A.E.; El-Gendy, A.O.; El-Gendy, A.O.; Islam, M. Measuring susceptibility of Candida albicans biofilms towards antifungal agents. Der Pharm. Lett. 2013, 5, 376-383.

25. El-Gendy, A.O.; Essam, T.M.; Amin, M.A.; Ahmed, S.H.; Nes, I.F. Clinical Screening for Bacteriocinogenic Enterococcus faecalis Isolated from Intensive Care Unit Inpatient in Egypt. J. Microb. Biochem. Technol. 2012, 4, 161-167.

26. Sader, H.S.; Flamm, R.K.; Jones, R.N. Antimicrobial activity of daptomycin tested against Gram-positive pathogens collected in Europe, Latin America, and selected countries in the Asia-Pacific Region. Diagn. Microbiol. Infect. Dis. 2013, 75, 417-422.

27. Tarek, N.; Hassan, H.M.; AbdelGhani, S.M.; Radwan, H.O.; El-Gendy, A.O. Comparative chemical and anti-microbial study of nine essential oils obtained from medicinal plants growing in Egypt. Beni Suef Univ. J. Basic Appl. Sci. 2014, 3, 149-156.

28. Ou, B.; Hampsch-Woodill, M.; Prior, R.L. Development and validation of improved oxygen radical absorbance capacity assay using fluorescein as the fluorescent probe. J. Agric. Food. Chem. 2001, 49, 4619-4626.

29. Gridling, M.; Stark, N.; Madlener, S.; Lackner, A.; Popescu, R.; Benedek, B.; Diaz, R.; Tut, F.M.; Nha Vo, T.P.; Huber, D.; et al. In vitro anti-cancer activity of two ethno-pharmacological healing plants from Guatemala Pluchea odorata and Phlebodiumdecumanum. Int. J. Oncol. 2009, 34, 1117-1128.

30. Madlener, S.; Svacinova, J.; Kitner, M.; Kopecky, J.; Eytner, R.; Lackner, A.; Vo, T.P.; Frisch, R.; Grusch, M.; de Martin, R.; et al. In vitro anti-inflammatory and anti-cancer activities of extracts of Acalypha alopecuroidea (Euphorbiaceae). Int. J. Oncol. 2009, 35, 881-891.

Sample Availability: Samples of the compounds 9, 12, 14, 15, 17a-c are available from the authors.

(C) 2015 by the authors; licensee MDPI, Basel, Switzerland. This article is an open access article distributed under the terms and conditions of the Creative Commons Attribution license (http://creativecommons.org/licenses/by/4.0/). 